\title{
Stable climate and surface mass balance in Svalbard over 1979-2013 despite the Arctic warming
}

\author{
C. Lang, X. Fettweis, and M. Erpicum \\ Département de Géographie, Université de Liège, Liège, Belgium \\ Correspondence to: C. Lang (charlotte.lang@ulg.ac.be)
}

Received: 30 June 2014 - Published in The Cryosphere Discuss.: 18 August 2014

Revised: 11 November 2014 - Accepted: 12 November 2014 - Published: 8 January 2015

\begin{abstract}
With the help of the regional climate model MAR (Modèle Atmosphérique Régional) forced by the ERAInterim reanalysis (MAR ERA$_{\text {) }}$ and the MIROC5 (Model for Interdisciplinary Research on Climate) global model

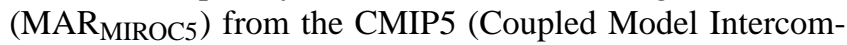
parison Project) database, we have modelled the climate and surface mass balance of Svalbard at a $10 \mathrm{~km}$ resolution over 1979-2013. The integrated total surface mass balance (SMB) over Svalbard modelled by MAR $\mathrm{ERA}_{\mathrm{EA}}$ is negative $\left(-1.6 \mathrm{Gt} \mathrm{yr}^{-1}\right)$ with a large interannual variability $(7.1 \mathrm{Gt})$ but, unlike over Greenland, there has been no acceleration of the surface melt over the past 35 years because of the recent change in atmospheric circulation bringing northwesterly flows in summer over Svalbard, contrasting the recent observed Arctic warming. However, in 2013, the atmospheric circulation changed to a south-southwesterly flow over Svalbard causing record melt, SMB $\left(-20.4 \mathrm{Gt} \mathrm{yr}^{-1}\right)$ and summer temperature. MIROC5 is significantly colder than ERA-Interim over 1980-2005 but MAR MIROC5 $_{\text {is able }}$ to improve the near-surface MIROC5 results by simulating not significant SMB differences with MAR $\mathrm{BRA}_{\mathrm{E}}$ over 1980-2005. On the other hand, MIROC5 does not represent the recent atmospheric circulation shift in summer and in-

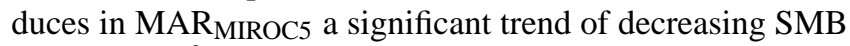
$\left(-0.6 \mathrm{Gt} \mathrm{yr}^{-2}\right)$ over $1980-2005$.
\end{abstract}

\section{Introduction}

In the context of global warming, it is important to evaluate the impact of climate change on high latitude zones, that are known to be very sensitive to a rise in temperature (IPCC AR5, 2013). Over 1961-2004, the Arctic has been the second largest contribution (excluding the Antarctic and Greenland ice sheets) to sea level rise (Kaser et al., 2006). According to Gardner et al. (2013) and Shepherd et al. (2012), between 2003 and 2009, glaciers and ice caps (including peripheral glaciers in Greenland and Antarctica) have contributed to sea level rise as much as the Greenland and Antarctic ice sheets, contributing together to $61 \%$ of the total sea level rise. Arctic ice loss represents almost $50 \%$ of the total glacier and ice caps loss but Svalbard contributed to only $4 \%$ of the total Arctic contribution (Gardner et al., 2013).

Svalbard seems to be the ice cap least sensitive to the recent Arctic warming in summer (Serreze et al., 2009) and while melt records have been broken several times in Greenland in the second half of the 2000s (Fettweis et al., 2013a), the surface mass balance (SMB) of Svalbard has been closer to balance after 2004 (Moholdt et al., 2010). Fettweis et al. (2013a) attributed it to atmospheric circulation changes in summer damping the warming over Svalbard, as we will discuss in Section 4. However, this recent stabilisation of the Svalbard SMB needs to be seen from a larger perspective, which has been missed until now.

The Svalbard (surface) mass balance has already been intensively studied but previously published studies involved either long time series but on only a few glaciers or over extended areas but on a shorter timescale and mostly used statistically or empirically based mass balance models. On a local scale (i.e. on one or a few glaciers), various types of mass balance reconstructions using different tools have been performed over Svalbard: Lefauconnier and Hagen (1990) used correlations between the measured mass balance and climatic parameters measured at Ny-Ålesund weather station (northwestern coast of Spitsbergen), Rasmussen and Kohler (2007) used a model running with meteorological data from 
NCEP/NCAR reanalysis, de Woul and Hock (2005) used a Positive Degree-Day (PDD) model and temperature and precipitation data from Ny-Ålesund. Energy balance models have also been used: van Pelt et al. (2012) used an energy balance model coupled to a snow model forced by the regional climate model (RCM) RACMO on Nordenskiöldbreen and Rye et al. $(2010,2012)$ used a coupled surfacesubsurface energy balance model forced by the ERA-40 reanalysis to reconstruct the SMB of Midre Lovénbreen. On a larger scale, Schuler et al. (2007) have modelled the surface mass balance of the Austfonna ice cap with a model based on weather data and SMB measurements. Førland et al. (2011) used the $25 \mathrm{~km}$ outputs of the NorACIA-RCM (Førland et al., 2009) to statistically downscale temperature and precipitation at the location of several weather stations and Benestad et al. (2002) empirically downscaled temperature using principal component analysis. Day et al. (2012) compared precipitation from the HadRM3 RCM $(25 \mathrm{~km})$ to the SMB measurements from Pinglot et al. (1999) and performed future projections of the Svalbard climate. Finally, Bamber et al. $(2004,2005)$ estimated elevation changes of glaciers and ice caps between 1996 and 2002 using airborne lasers and, more recently, Moholdt et al. (2010) computed elevation changes from 2003 to 2008 based on measurements made by the ICESat satellite.

Knowing that the SMB (precipitation contributing to the accumulation and melt caused by positive temperature) is the component of mass balance most sensitive to climate change, this necessitates the study of the SMB over the entirety of Svalbard on a longer time period, in view of the current apparent stabilisation of the Svalbard SMB in full opposition to the other Arctic ice caps. To do so, regional climate models (RCMs), fully coupled with energy balance models are ideal tools. Indeed, they allow high spatial resolution simulations with models that are calibrated for specific regions. In addition, the RCMs also give us the opportunity to perform more reliable future projections compared to forced energy balance models, which do not simulate the surface albedo positive feedback for example.

Among the available RCMs, the regional climate model MAR (Modèle Atmosphérique Régional) has been extensively evaluated over Greenland and is able to accurately simulate the Greenland ice sheet SMB (e.g. Fettweis et al. (2013b) and Franco et al. (2013) and references therein). That is why we propose here to study the current (19792013) SMB evolution over the entirety of Svalbard with MAR at a resolution of $10 \mathrm{~km}$. Both the ERA-Interim reanalysis (Dee et al., 2011) and the global model MIROC5 (Model for Interdisciplinary Research on Climate) (Watanabe et al., 2010; Sakamoto et al., 2012) from the CMIP5 (Coupled Model Intercomparison Project) database were used to force MAR over the current climate. The MIROC5 model has been chosen as it is one of the best CMIP5 models for simulating the current climate and atmospheric circulation over Green- land and surrounding areas with respect to ERA-Interim (Fettweis et al., 2013b).

Section 2 of this article gives a description of MAR and the forcings of our simulations. Section 3 evaluates MAR over Svalbard by comparing its results to near-surface measurements from weather stations and SMB measurements. We discuss its results over the current climate in Sect. 4. In Sect. 5, we compare ERA-Interim with MIROC5 over Svalbard as well as MAR forced by both of those in Sect. 6, with the aim of performing future projections in a companion paper (Lang et al., 2014).

\section{Model and forcings}

\subsection{The MAR model}

MAR (Modèle Atmosphérique Régional) is a regional atmospheric climate model specifically developed for the study of polar regions (Gallée and Schayes, 1994) and consists of an atmospheric model coupled with the surface model SISVAT (Soil Ice Snow Vegetation Atmosphere Transfer) (de Ridder and Gallée, 1998; Gallée et al., 2001) through the exchange of energy fluxes, momentum, precipitation, etc.

The SISVAT model is a vertical 1-D multi-layered model consisting of a soil/vegetation module and a snow/ice energy balance module resolving most of the processes occurring at the surface of the snow/ice pack and is based on the CROCUS model (Brun, 1989) from the CEN (Centre d'Études de la Neige).

The soil/vegetation module simulates the exchanges of heat and moisture with the atmosphere above the land without snow or ice while the snow/ice module deals with the exchanges between the atmosphere and the sea ice, the glaciers and ice sheets and the snow covering the land. Snow layers are characterised by their temperature, density, height, age, liquid water content, dendricity and sphericity of the crystals and grain size. These snow properties evolve with time in the snow metamorphism module according to Brun (1989). The energy balance between the soil and the snow is computed in the thermodynamic module through the absorbed shortwave flux, the longwave fluxes (upward and downward), the sensible and latent heat fluxes at the surface, the melting and sublimation of snow/ice and evaporation and refreezing of the meltwater heat fluxes, the heat fluxes due to precipitation (solid and liquid), condensation and deposition and the heat flux from the ground.

The model is not coupled with a 3-D ice sheet model, which prevents us from modelling dynamical processes and constrains us to use a fixed topography and ice extent throughout the entire simulation. That is why we focus only on the surface mass balance. The MAR version used here is 3.3 and the configuration is the one used in Fettweis et al. (2013b). 

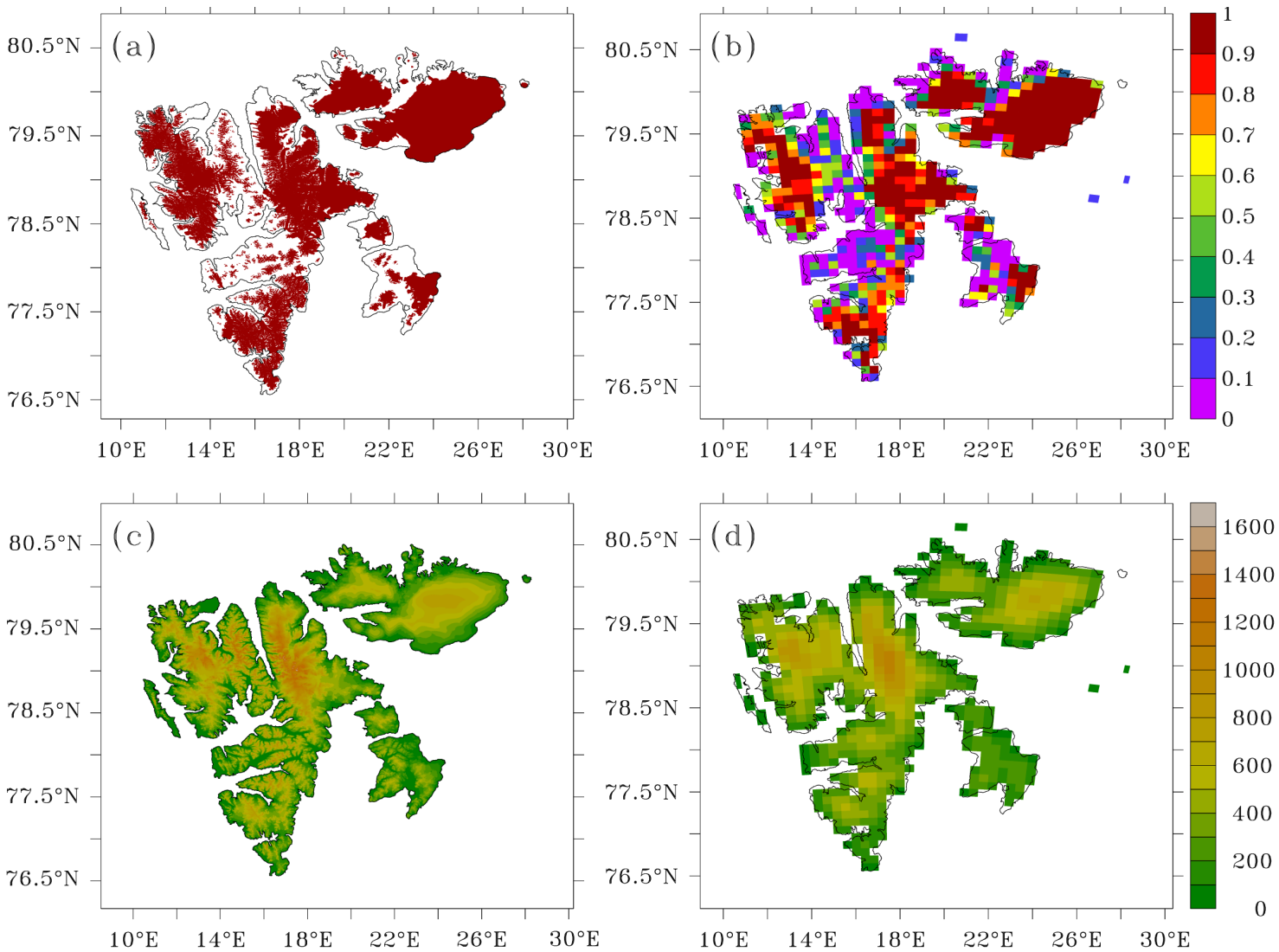

Figure 1. (a) Permanent ice mask from Nuth et al. (2013) interpolated on a $250 \mathrm{~m}$ grid. (b) Permanent $10 \mathrm{~km}$ fractional ice mask as used in MAR. (c) Svalbard topography (ma.s.l.) from the Norsk Polarinstitutt interpolated on a $250 \mathrm{~m}$ grid. (d) $10 \mathrm{~km}$ topography as used in MAR (ma.s.1.).

Table 1. Stations used for validation. Period over which data are available, coordinates and elevation of the stations (m), elevation of the corresponding model pixel used in the validation $(\mathrm{m})$ and distance between the station and the pixel $(\mathrm{km})$.

\begin{tabular}{|c|c|c|c|c|c|c|c|c|c|c|c|}
\hline \multirow[t]{2}{*}{ Station } & \multicolumn{2}{|c|}{ Period observation } & \multirow{2}{*}{\multicolumn{2}{|c|}{ Coordinates }} & \multirow{2}{*}{$\begin{array}{l}\text { Elev } \\
(\mathrm{m})\end{array}$} & \multicolumn{3}{|c|}{ Pixel elev (m) } & \multicolumn{3}{|c|}{ Dist station-pixel $(\mathrm{km})$} \\
\hline & Temperature & Precipitation & & & & MAR & ERA & ASR & MAR & ERA & ASR \\
\hline Hornsund & $2005-2013$ & 1996-2013 & $77.00^{\circ} \mathrm{N}$ & $15.50^{\circ} \mathrm{E}$ & 10 & 178 & 22 & 227 & 6.0 & 57.0 & 36.8 \\
\hline Kapp Heuglin & 2006-2013 & - & $78.25^{\circ} \mathrm{N}$ & $22.82^{\circ} \mathrm{E}$ & 14 & 54 & 87 & 166 & 6.7 & 28.7 & 21.9 \\
\hline Ny-Ålesund & 1979-2013 & 1979-2013 & $78.92^{\circ} \mathrm{N}$ & $11.93^{\circ} \mathrm{E}$ & 8 & 137 & 215 & 361 & 3.3 & 64.5 & 52.3 \\
\hline Svalbard Lufthavn & 1979-2013 & 1979-2013 & $78.25^{\circ} \mathrm{N}$ & $14.47^{\circ} \mathrm{E}$ & 28 & 188 & 214 & 242 & 4.2 & 30.3 & 13.4 \\
\hline Sveagruva & 1979-2013 & 1979-2002 & $77.88^{\circ} \mathrm{N}$ & $16.72^{\circ} \mathrm{E}$ & 9 & 284 & 234 & 247 & 1.1 & 54.1 & 57.9 \\
\hline
\end{tabular}

\subsection{Model forcings}

We have run MAR over the period 1979-2013 at a spatial resolution of $10 \mathrm{~km}$. The lateral and oceanic boundaries were forced every $6 \mathrm{~h}$ (temperature, wind and humidity at each vertical level as well as sea surface temperature and sea-ice cover over the ocean) by the ERA-Interim (MARERA) reanalysis $\left(0.75^{\circ}\right.$ resolution) and the MIROC5 (MAR MIROC5) general circulation model $\left(1.4^{\circ}\right.$ resolution). The reanalysis and the GCM fields were also used to initialise the simulations at the beginning (1 September 1974). Five years of spin-up are required to reduce the impact of the snowpack initialisation (in particular the snow density) on our results.

\subsection{Errors in the $10 \mathrm{~km}$ interpolated topography}

The fractional permanent ice mask and topography used in MAR over Svalbard (Fig. 1b and d) have been interpolated at $10 \mathrm{~km}$ from the glacier inventory of Nuth et al. (2013) (Fig. 1a) and from the topography from the Norsk Polarinstitutt (NPI) respectively (Fig. 1c). Both shapefile data sets had previously been interpolated on a $250 \mathrm{~m}$ grid to produce 
Table 2. 1979-2013 mean annual and summer correlation $\left(R^{2}\right)$, RMSE and bias $\left({ }^{\circ} \mathrm{C}\right)$ between MARERA and the observed daily temperature and percentage of missing observations (\% MO).

\begin{tabular}{|c|c|c|c|c|c|c|c|c|}
\hline \multirow[t]{2}{*}{ Station } & \multicolumn{4}{|c|}{ Annual } & \multicolumn{4}{|c|}{ Summer } \\
\hline & $R^{2}$ & $\operatorname{RMSE}\left({ }^{\circ} \mathrm{C}\right)$ & $\operatorname{Bias}\left({ }^{\circ} \mathrm{C}\right)$ & $\% \mathrm{MO}$ & $R^{2}$ & $\operatorname{RMSE}\left({ }^{\circ} \mathrm{C}\right)$ & $\operatorname{Bias}\left({ }^{\circ} \mathrm{C}\right)$ & $\% \mathrm{MO}$ \\
\hline Hornsund & 0.94 & 3.79 & -3.25 & 21 & 0.48 & 2.81 & -2.45 & 21 \\
\hline Kapp Heuglin & 0.93 & 3.66 & -2.48 & 32 & 0.78 & 1.35 & -0.68 & 38 \\
\hline Ny-Ålesund & 0.94 & 2.49 & -1.31 & 3 & 0.74 & 2.60 & -2.27 & 1 \\
\hline Svalbard Lufthavn & 0.93 & 3.66 & -2.77 & 1 & 0.72 & 3.30 & -2.91 & 0 \\
\hline Sveagruva & 0.92 & 4.92 & -4.00 & 3 & 0.65 & 4.39 & -4.08 & 5 \\
\hline
\end{tabular}

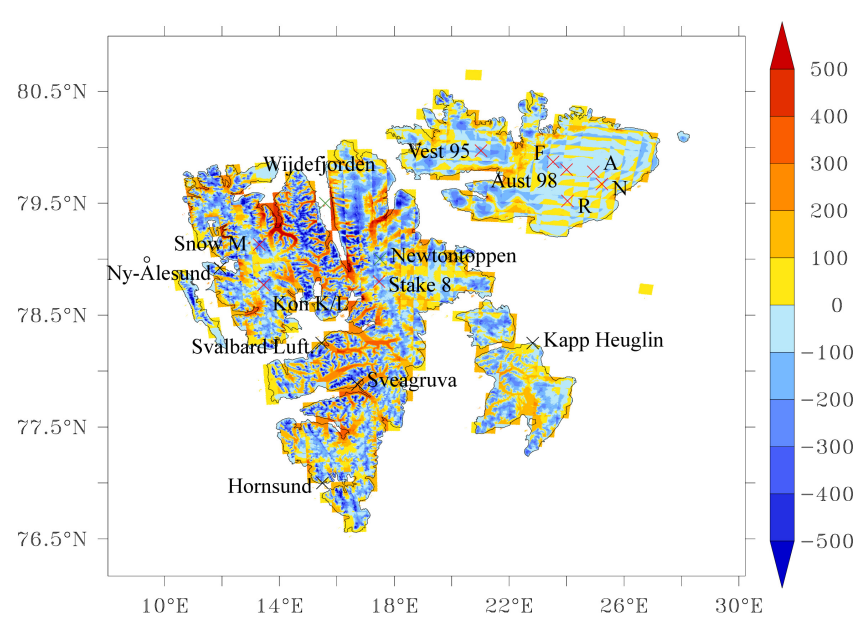

Figure 2. Elevation difference $(\mathrm{m})$ between the $10 \mathrm{~km}$ MAR topography (based on the topography of the Norsk Polarinstitutt - NPI) and the topography of the NPI interpolated on a $250 \mathrm{~m}$ grid. The black $\mathrm{X}$ show the location of the weather stations used in the validation and the red ones show the location of the stakes from Pinglot et al. $(1999,2001)$.

files that can be read by MAR. The total area (Kvitøya excluded) of the ice mask is $33264 \mathrm{~km}^{2}$, which is about $55 \%$ of the total land surface. With the $10 \mathrm{~km}$ interpolated ice mask, the total permanent ice area is $30042 \mathrm{~km}^{2}$ and corresponds to $49 \%$ of the $10 \mathrm{~km}$ interpolated land surface.

In version 3 of MAR, the ice mask is fractional, i.e. each pixel is associated with a proportion of its area that is covered with permanent ice (Fig. 1b). In our analysis, the ice sheet area corresponds to the pixels covered with at least $50 \%$ of permanent ice. If not, we consider these pixels to be the tundra zone. In all calculations showing integrated values over the entire ice sheet, we have computed weighted averages according to the percentage of ice covering each ice pixel (i.e. having a permanent ice area higher than $50 \%$ ).

Figure 2 shows that using a resolution of $10 \mathrm{~km}$ underestimates the elevation, especially on both sides of Wijdefjorden (northern Spitsbergen) where the difference is greater than $500 \mathrm{~m}$ due to a very steep topography.
We have divided the elevation range into 16 classes (Supplement Table S1) and computed the mean elevation error between the interpolated $10 \mathrm{~km}$ elevation (as used in MAR) and the $250 \mathrm{~m}$ topography, as well as the mean absolute error. The mean error gives an indication of whether a certain elevation range is underestimated (negative value) or overestimated (positive value) in the MAR topography, and the absolute error gives the mean value of the elevation bias, regardless of its sign. Due to the smoothing of the topography at a resolution of $10 \mathrm{~km}$, the topography used in our MAR simulations underestimates all the elevations above $1000 \mathrm{~m}$ (classes 11 to 16) whereas for classes 3 to $10(200-1000 \mathrm{~m})$, the elevation is mostly underestimated but there are also areas where it is overestimated in the MAR topography. Finally, close to the coastline, where the elevation is lower than $200 \mathrm{~m}$, the MAR topography slightly overestimates the elevation for most of the pixels.

As a consequence of the elevation underestimation at a resolution of $10 \mathrm{~km}$, a lot of glaciers are too low in altitude in MAR than in reality, which could impact their simulated surface mass balance as shown by Lenaerts et al. (2013), who found that the bias increases when the SMB is increasingly negative. In extreme cases, some glaciers at a resolution of $10 \mathrm{~km}$ could be at such low elevations that they should not even exist under the present climate in the $10 \mathrm{~km}$ grid. As a result, the accumulation zone is missing and the melt is overestimated and could introduce a bias when considering the integrated surface mass balance of Svalbard. However, the interannual variability of the surface mass balance should not significantly be affected by the smoothing of the topography at a resolution of $10 \mathrm{~km}$. Based on the histogram (Supplement Fig. S1), corrections of the SMB integrated over the entirety of Svalbard will be given in Section 4. Finally, as we consider only the pixels covered with more than $50 \%$ of ice to be ice pixels, a lot of small glaciers (corresponding to $10 \%$ of the permanent ice area) are left out of our analysis.

\section{Evaluation of MAR forced by ERA-Interim}

In order to evaluate our model over the present climate, we have compared the MAR results (called MAR $_{\mathrm{ERA}}$ hereafter) 
Table 3. 1979-2013 mean annual and summer correlation $\left(R^{2}\right)$, RMSE and bias $\left({ }^{\circ} \mathrm{C}\right)$ between the ERA-Interim reanalysis and the observed temperature.

\begin{tabular}{lccrrrrr}
\hline Station & \multicolumn{3}{c}{ Annual } & & \multicolumn{3}{c}{ Summer } \\
\cline { 2 - 3 } \cline { 7 - 8 } & $R^{2}$ & $\operatorname{RMSE}\left({ }^{\circ} \mathrm{C}\right)$ & $\operatorname{Bias}\left({ }^{\circ} \mathrm{C}\right)$ & & $R^{2}$ & $\operatorname{RMSE}\left({ }^{\circ} \mathrm{C}\right)$ & $\operatorname{Bias}\left({ }^{\circ} \mathrm{C}\right)$ \\
\hline Hornsund & 0.94 & 3.01 & 2.24 & & 0.57 & 1.31 & 0.63 \\
Kapp Heuglin & 0.95 & 2.18 & 1.14 & & 0.66 & 1.54 & 0.55 \\
Ny-Ålesund & 0.93 & 3.03 & -1.95 & & 0.78 & 2.33 & -2.00 \\
Svalbard Lufthavn & 0.96 & 2.31 & -1.40 & & 0.79 & 2.12 & -1.66 \\
Sveagruva & 0.93 & 2.75 & -1.07 & & 0.72 & 2.40 & -1.98 \\
\hline
\end{tabular}

Table 4. 1979-2013 mean annual measured precipitation $\left(\mathrm{mm} \mathrm{yr}^{-1}\right)$, proportion of that precipitation that is simulated by MARERA and percentage of missing observations (\% MO).

\begin{tabular}{lccr}
\hline Station & Pobs $\left(\mathrm{mm} \mathrm{yr}^{-1}\right)$ & Pmod/Pobs & $\%$ MO \\
\hline Hornsund & 378 & 1.16 & 50 \\
Kapp Heuglin & - & - & 100 \\
Ny-Ålesund & 409 & 0.77 & 47 \\
Svalbard Lufthavn & 187 & 1.52 & 39 \\
Sveagruva & 252 & 1.52 & 42 \\
\hline
\end{tabular}

forced by ERA-Interim from ECMWF (Dee et al., 2011) over 1979-2013 to near-surface measurements of temperature and precipitation from weather stations as well as surface mass balance measurements. For comparison, these weather measurements have also been compared to the ASR (Wilson et al., 2011) and the ERA-Interim reanalysis, knowing that no observation is assimilated into the MAR model.

\subsection{Comparison of MAR with weather stations}

First, we have compared the daily near-surface temperature (TAS) of the stations listed in Table 1 and shown in Fig. 2 to

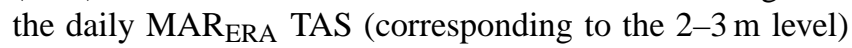
of the pixel that is the closest to each station. As 1979 is the first year of ERA-Interim reanalysis, the comparison has been made over 1979-2013 when data were available.

While MAR is too cold compared to the observations, the daily variability of the temperature is very well simulated by MAR (Table 2). Part of these biases are however caused by the overestimation of the stations' elevation in MAR induced by the used $10 \mathrm{~km}$ resolution and the very steep topography near the coast. However, given the values of both temperature and elevation biases, MAR is anyway too cold even if no elevation bias was present as the temperature vertical gradient is $1^{\circ} \mathrm{C} 100 \mathrm{~m}^{-1}$ at its maximum. As summer temperature has more impact on the surface mass balance (through the melt) than the annual mean temperature, we have separately evaluated the JJA (June, July and August) temperatures. In summer, the MAR cold bias is smaller than the annual bias at Hornsund and Kapp Heuglin and comparable at Svalbard
Lufthavn and Sveagruva and the RMSE is smaller at every station except Ny-Ålesund. The daily observed variability is however less well reproduced by MAR in summer.

The main effect of this MAR cold bias on the modelled SMB is a likely underestimation of the amount of melt in summer. Colder air can also contain less moisture and therefore a cold bias should imply an underestimation of snowfall. However, it is the temperature in altitude that influences the moisture content rather than TAS, and a negative TAS bias does not necessarily mean that the free atmosphere temperature bias will also be cold. It is therefore difficult to interpret the TAS cold bias in terms of snowfall underestimation. Moreover, the weather stations used in the validation are all located at the coast and most of them in fjords. As the resolution of ERA-Interim is too low to represent those fjords, we interpolated the ERA-Interim sea-ice cover (SIC) and sea surface temperature (SST) on the $10 \mathrm{~km}$ grid, then extrapolated SIC and SST in the fjords using the values of the nearest pixels. But this extrapolated SIC/SST may not be representative of the SIC/SST of the fjords and therefore could cause a temperature bias that would not be present further inland, as the ocean conditions influences the coastal regions a lot. However, we have no observations far inland and in the free atmosphere to confirm this.

It is well known that the outputs of regional climate models are strongly dependent on the reanalysis or global model used to force their boundaries. However, as the MAR and ERA-Interim reanalysis biases (Table 3) are different and of opposite signs for some of the stations (MAR is too cold while ERA-Interim is too warm), this shows well that MAR is totally free in the boundary layer and that the MAR cold bias does not come from the lateral boundaries. Moreover, in Ny-Ålesund, the MAR bias averaged over 2000-2010 (Supplement Table S2) is smaller than the ASR bias (Supplement Table S3), both on the annual timescale and during summer. This suggests that MAR compares well with other model outputs using data assimilation. On the annual timescale, MAR is better than ASR at reproducing the daily variability of the temperature for every station and comparable to ERA whereas in summer, the three products are comparable.

MAR underestimates the annual mean amount of precipitation at Ny-Ålesund and overestimates it at the other three 
Table 5. Sites of Pinglot et al. (1999, 2001) used in the comparison.

\begin{tabular}{lcccccc}
\hline Stake & Coordinates & $\begin{array}{c}\text { Elevation } \\
\text { stake }(\mathrm{m})\end{array}$ & $\begin{array}{c}\text { Elevation } \\
\text { MAR }(\mathrm{m})\end{array}$ & $\begin{array}{c}\text { Distance } \\
\text { pixel-stake } \\
(\mathrm{km})\end{array}$ & Period \\
\hline Stake 8 & $78^{\circ} 48^{\prime} \mathrm{N}$ & $17^{\circ} 28^{\prime} \mathrm{E}$ & 1173 & 895 & 3.66 & $1986-1996$ \\
Kon K & $78^{\circ} 47^{\prime} \mathrm{N}$ & $13^{\circ} 17^{\prime} \mathrm{E}$ & 639 & 586 & 4.77 & $1986-1988$ \\
Kon L & $78^{\circ} 46^{\prime} \mathrm{N}$ & $13^{\circ} 27^{\prime} \mathrm{E}$ & 726 & 586 & 4.63 & $1986-1991$ \\
Snow M & $79^{\circ} 08^{\prime} \mathrm{N}$ & $13^{\circ} 18^{\prime} \mathrm{E}$ & 1170 & 849 & 4.62 & $1986-1991$ \\
Vest 95 & $79^{\circ} 58^{\prime} \mathrm{N}$ & $21^{\circ} 01^{\prime} \mathrm{E}$ & 600 & 478 & 4.78 & $1986-1994$ \\
$\mathrm{~F}$ & $79^{\circ} 52^{\prime} \mathrm{N}$ & $23^{\circ} 32^{\prime} \mathrm{E}$ & 727 & 651 & 3.09 & $1986-1999$ \\
Aust 98 & $79^{\circ} 48^{\prime} \mathrm{N}$ & $24^{\circ} 00^{\prime} \mathrm{E}$ & 740 & 710 & 2.26 & $1986-1997$ \\
$\mathrm{~A}$ & $79^{\circ} 50^{\prime} \mathrm{N}$ & $24^{\circ} 56^{\prime} \mathrm{E}$ & 729 & 623 & 3.72 & $1986-1998$ \\
$\mathrm{~N}$ & $79^{\circ} 40^{\prime} \mathrm{N}$ & $25^{\circ} 14^{\prime} \mathrm{E}$ & 491 & 518 & 3.76 & $1986-1999$ \\
$\mathrm{R}$ & $79^{\circ} 31^{\prime} \mathrm{N}$ & $24^{\circ} 02^{\prime} \mathrm{E}$ & 511 & 469 & 1.82 & $1986-1999$ \\
\hline
\end{tabular}

Table 6. Annual measured SMB (mw.e. $\mathrm{yr}^{-1}$ ) from Pinglot et al. $(1999,2001)$ and simulated by MARERA, SMB difference $(\%$ and $\mathrm{m} w . e . \mathrm{yr}^{-1}$ ) between the MAR outputs and the measurements, MAR interannual variability of the SMB ( $\mathrm{mw}^{\mathrm{e}}$. $\mathrm{yr}^{-1}$ ). MAE $=\mathrm{Mean}^{\mathrm{abs}-}$ lute error.

\begin{tabular}{|c|c|c|c|c|c|}
\hline \multirow[t]{2}{*}{ Stake } & \multicolumn{2}{|c|}{$\begin{array}{c}\text { Mean annual } \\
\left.\text { SMB (mw.e. } \mathrm{yr}^{-1}\right)\end{array}$} & \multirow{2}{*}{\multicolumn{2}{|c|}{$\begin{array}{l}\text { SMB difference } \\
(\%) \quad\left(\mathrm{m} \text { w.e. } \mathrm{yr}^{-1}\right)\end{array}$}} & \multirow{2}{*}{$\begin{array}{c}\text { MAR interannual } \\
\text { variability } \\
\left(\mathrm{m} \text { w.e. } \mathrm{yr}^{-1}\right)\end{array}$} \\
\hline & Pinglot & MAR & & & \\
\hline Stake 8 & 0.75 & 0.74 & -1.3 & -0.01 & 0.18 \\
\hline Kon K & 0.48 & 0.28 & -41.7 & -0.20 & 0.28 \\
\hline Kon L & 0.62 & 0.31 & -50.0 & -0.31 & 0.19 \\
\hline Snow M & 0.57 & 0.67 & 17.5 & 0.10 & 0.18 \\
\hline Vest 95 & 0.41 & 0.30 & -26.8 & -0.11 & 0.18 \\
\hline $\mathrm{F}$ & 0.37 & 0.37 & 0.0 & 0.00 & 0.26 \\
\hline Aust 98 & 0.52 & 0.46 & -11.5 & -0.06 & 0.17 \\
\hline A & 0.42 & 0.43 & 2.4 & 0.01 & 0.24 \\
\hline $\mathrm{N}$ & 0.20 & 0.34 & 70.0 & 0.14 & 0.26 \\
\hline $\mathrm{R}$ & 0.23 & 0.29 & 26.1 & 0.06 & 0.27 \\
\hline MAE & & & 24.7 & 0.10 & \\
\hline
\end{tabular}

Table 7. 2003-2008 mean elevation changes ( $\left.\mathrm{d} h / \mathrm{d} t, \mathrm{~m} \mathrm{yr}^{-1}\right)$ from MAR $_{\text {ERA }}$ and Moholdt et al. (2010) for different regions.

\begin{tabular}{lrr}
\hline Region & \multicolumn{2}{c}{$\mathrm{d} h / \mathrm{d} t\left(\mathrm{~m} \mathrm{yr}^{-1}\right)$} \\
\cline { 2 - 3 } & MAR ERA $_{\text {Eoholdt et al. (2010) }}$ & Mon \\
\hline Austfonna & 0.00 & $0.11 \pm 0.04$ \\
Vestfonna & -0.14 & $-0.16 \pm 0.08$ \\
Northwest Spitsbergen & -0.22 & $-0.54 \pm 0.10$ \\
Northeast Spitsbergen & 0.02 & $0.06 \pm 0.06$ \\
South Spitsbergen & -0.45 & $-0.15 \pm 0.16$ \\
Barentsøya/Edgeøya & -0.38 & $-0.17 \pm 0.11$ \\
\hline Total & -0.13 & $-0.12 \pm 0.04$ \\
\hline
\end{tabular}

stations (Table 4). It is obvious that we can not resolve the complex spatial variability of precipitation along the coast at a resolution of $10 \mathrm{~km}$ but it is also difficult to gauge the snowfall amount in this windy region. Moreover, a lot of data are missing for all the stations. Therefore, we can not draw any conclusion about a likely overestimation of the MAR precipitation by using only precipitation measurements from coastal weather stations.

\subsection{Comparison of MAR with SMB measurements}

As validation of the SMB, we have compared MAR to SMB measurements from Pinglot et al. (1999) and Pinglot et al. (2001), as indicated in Tables 5 and 6 and Fig. 2.

The MAR model underestimates the SMB for 5 of the 10 sites and overestimates it for the remaining 5 (Table 6) so there is no systematic bias. The mean error is $-0.20 \mathrm{~m}$ w.e. $\mathrm{yr}^{-1}$, corresponding to $-2 \%$, and the absolute error is $0.10 \mathrm{mw}$.e. $\mathrm{yr}^{-1}$ (i.e. $25 \%$ ), but none of the differ- 

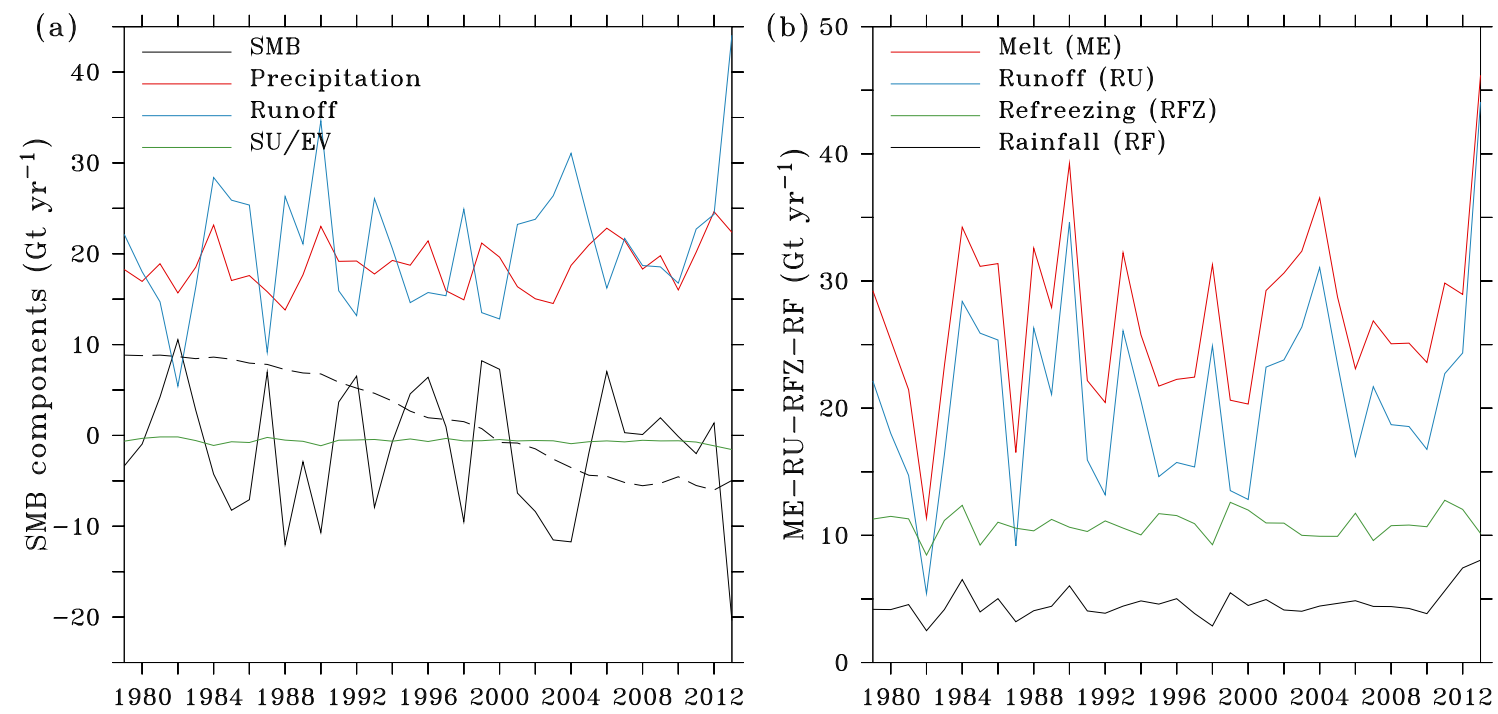

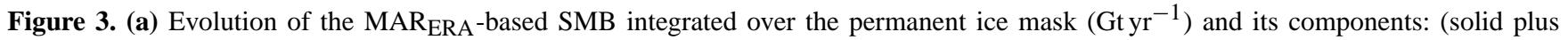
liquid) precipitation, meltwater runoff and sublimation and evaporation (SU/EV) over 1979-2013. The dashed black curve represents the MAR MIROC5-based SMB (after having applied a $10 \mathrm{yr}$ running mean). (b) Same as (a) but for the liquid water (melt, runoff and liquid precipitation) and refreezing $\left(\mathrm{Gt} \mathrm{yr}^{-1}\right)$.

Table 8. Comparison between SMB simulated by MAR ( $m m$ w.e. $\mathrm{yr}^{-1}$ ) and different studies. (1) The SMB estimate has been calculated as the net mass balance $\left(\mathrm{km}^{3} \mathrm{yr}^{-1}\right)$ minus the estimated calving flux from Błaszczyk et al. (2009) $\left(6.75 \mathrm{~km}^{3} \mathrm{yr}^{-1}\right)$, then converted in mm w.e. $\mathrm{yr}^{-1}$ by dividing it by the surface of the glaciated area. (2) The MAR ${ }_{\text {ERA }}$ SMB has been estimated over 1979-2013.

\begin{tabular}{|c|c|c|c|c|}
\hline Reference & Time period & $\begin{array}{c}\text { Mass balance } \\
\left(\mathrm{km}^{3} \mathrm{yr}^{-1}\right)\end{array}$ & $\begin{array}{c}\text { SMB estimate } \\
\left(\mathrm{mm}^{2} \text { w.e. } \mathrm{yr}^{-1}\right)^{(1)}\end{array}$ & $\begin{array}{c}\text { MAR }_{\text {ERA }} \text { estimate } \\
\left(\mathrm{mm} \text { w.e. } \mathrm{yr}^{-1}\right)\end{array}$ \\
\hline Mémin et al. (2011) & 2003-2008 & -9.1 & -65 & -98 \\
\hline Mémin et al. (2011) & 2003-2008 & -15.5 & -243 & -98 \\
\hline Mémin et al. (2011) & 1998-2007 & -25.0 & -508 & -88 \\
\hline Wouters et al. (2008) & 2003-2007 & -8.8 & -49 & -118 \\
\hline Nuth et al. (2010) & $65 / 90-03 / 07^{(2)}$ & -9.7 & -106 & -75 \\
\hline
\end{tabular}

ences are significant with respect to the MAR interannual variability (the difference is significant at the $95 \%$ confidence level if it is higher than twice the interannual variability of the MAR SMB).

On the Austfonna and Vestfonna ice caps, where the slopes are gentle and a resolution of $10 \mathrm{~km}$ is enough to represent the main variations of the topography, the SMB is generally well modelled, except for stake $\mathrm{N}$ where the difference is a bit larger $\left(0.14 \mathrm{mw}\right.$.e. $\mathrm{yr}^{-1}$, corresponding to a difference of $+70 \%)$. On Spitsbergen, on the contrary, the topography is so steep that a $10 \mathrm{~km}$ resolution is not enough to represent it and elevation biases are huge. The precipitation pattern is more complex than on the ice caps because of the "barrier effect" induced by the topography and, therefore, as a result of the elevation underestimation discussed in the previous section, there could be local precipitation biases influencing the modelled surface mass balance. For example, between Kongsvegen (Kon K and Kon L) and the ocean lies an area where the elevation is highly underestimated. At
Ny-Ålesund weather station, located in that area, the modelled precipitation is underestimated by $25 \%$. In our topography, the "barrier effect" of the elevated topography is not present and orographic precipitation may occur in another region. As a consequence, the SMB modelled at Kongsvegen is underestimated quite a lot $\left(-0.2\right.$ and $-0.31 \mathrm{mw}$.e. $\mathrm{yr}^{-1}$, corresponding to -42 and $-50 \%$ ). Using the WRF model (Weather Research and Forecasting), Claremar et al. (2012) investigated the effect of model resolution on wind speed in Svalbard, which strongly depends on the topography as does precipitation. They also conclude that, over very hilly topography, wind speed biases are large and a very high resolution is needed. From this comparison, we can conclude that MAR simulates well the surface mass balance but a resolution of $10 \mathrm{~km}$ is likely too coarse to model correctly the SMB and its components over Spitsbergen, where the topography is more complex.

Day et al. (2012) have compared some of the measurements from Pinglot et al. (1999) to the precipitation from the 
(a)

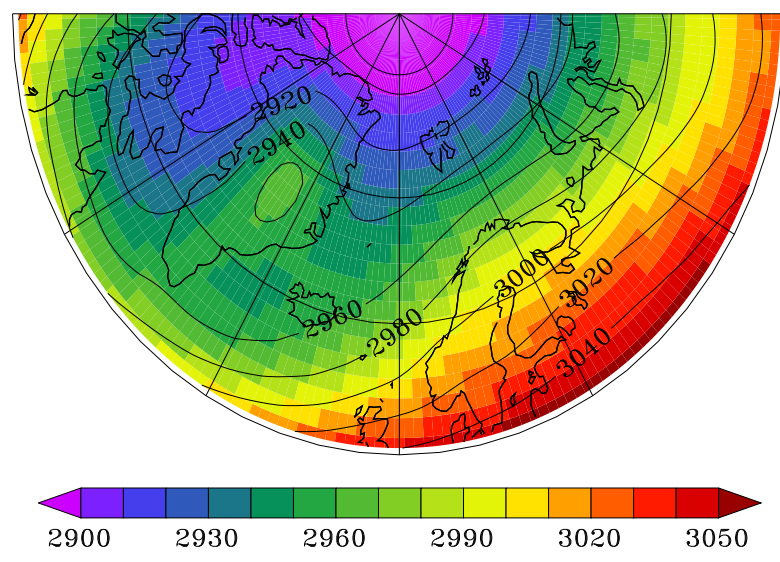

(b)

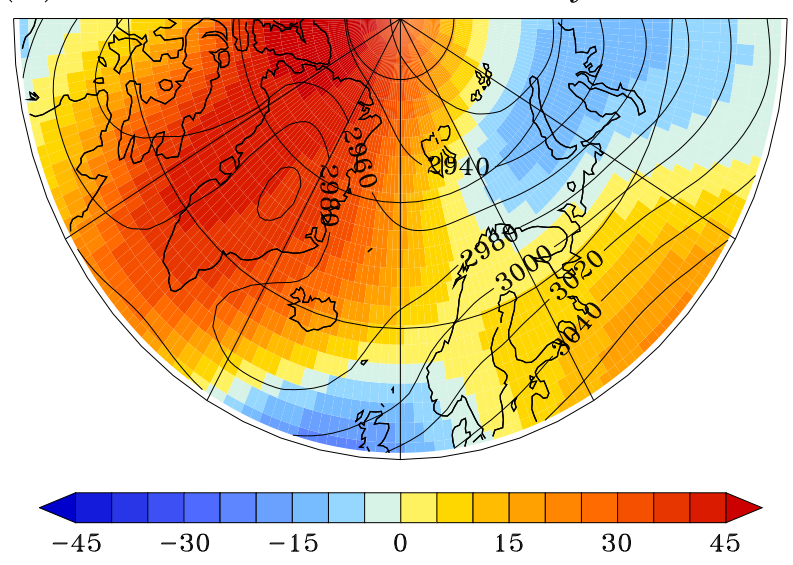

(c)

2013 anomaly

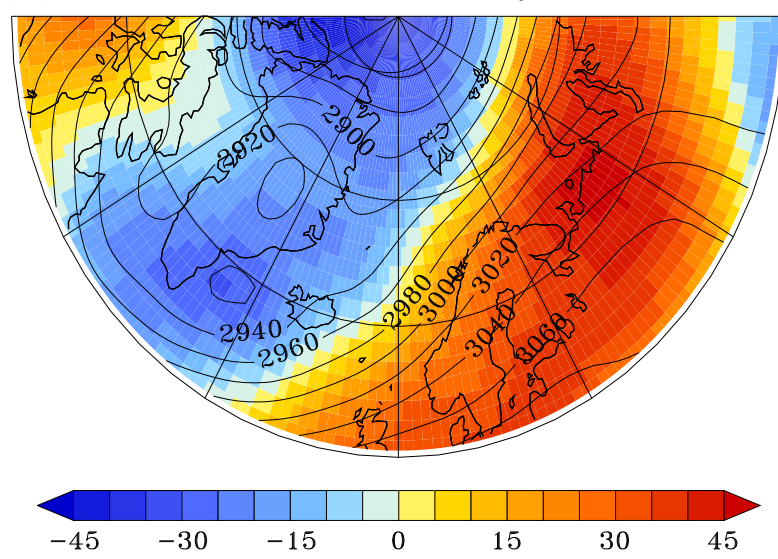

Figure 4. (a) Mean 1979-2005 JJA geopotential height at 700hPa $\left(\mathrm{Z} 700_{\mathrm{JJA}}\right)(\mathrm{m})$ from ERA-Interim. (b) 2006-2012 mean $\mathrm{z} 700_{\mathrm{JJA}}$ anomaly (m) with respect to the 1979-2005 mean. (c) Same as (b) but for 2013. The black lines represent the mean Z700 $_{\text {JJA }}$ for each period. (a) 1979-2005 mean

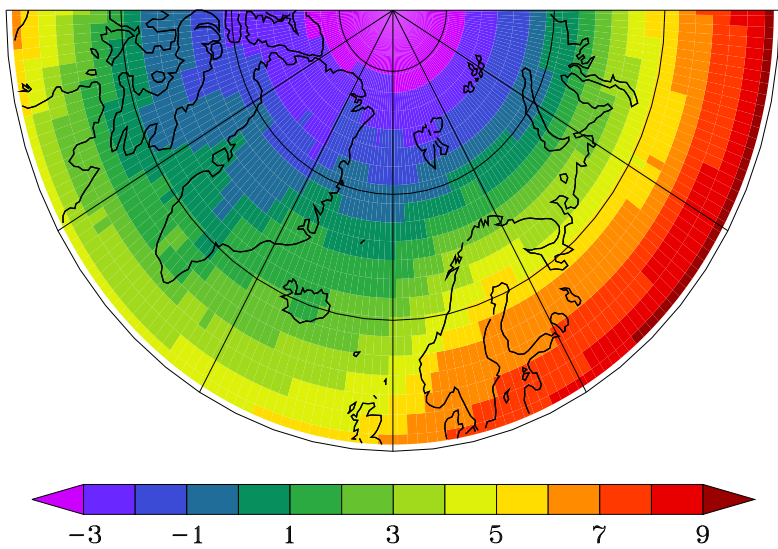

(b) 2006-2012 anomaly

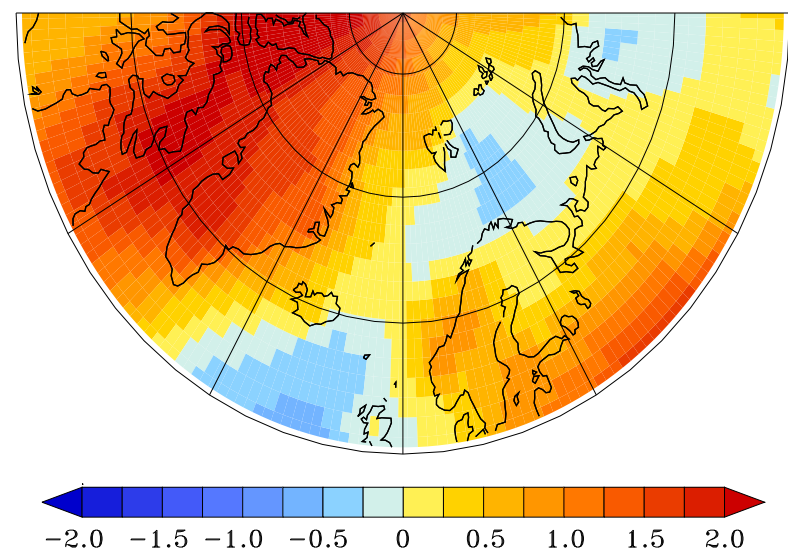

(c) 2013 anomaly

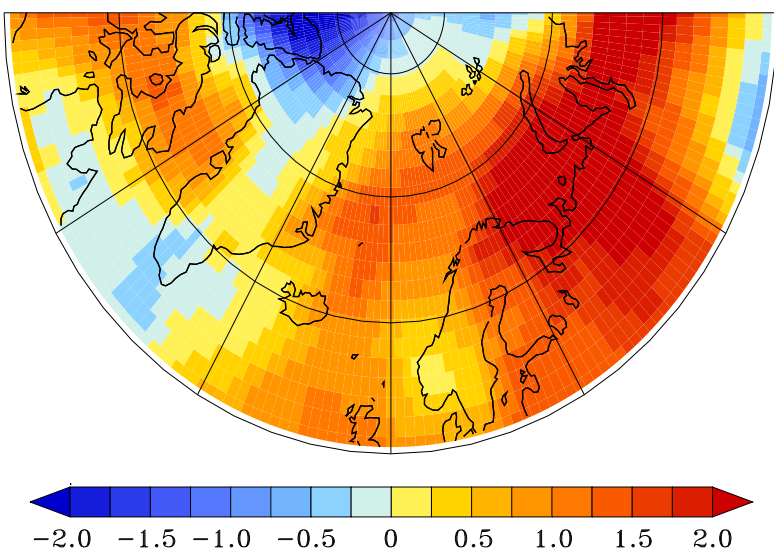

Figure 5. (a) $1979-2005 \mathrm{~T} 850_{\mathrm{JJA}}$ mean $\left({ }^{\circ} \mathrm{C}\right)$ from ERA-Interim. (b) 2006-2012 mean T850 $0_{\mathrm{JJA}}$ anomaly $\left({ }^{\circ} \mathrm{C}\right)$ with respect to the 1979-2005 mean. (c) Same as (b) but for 2013. 


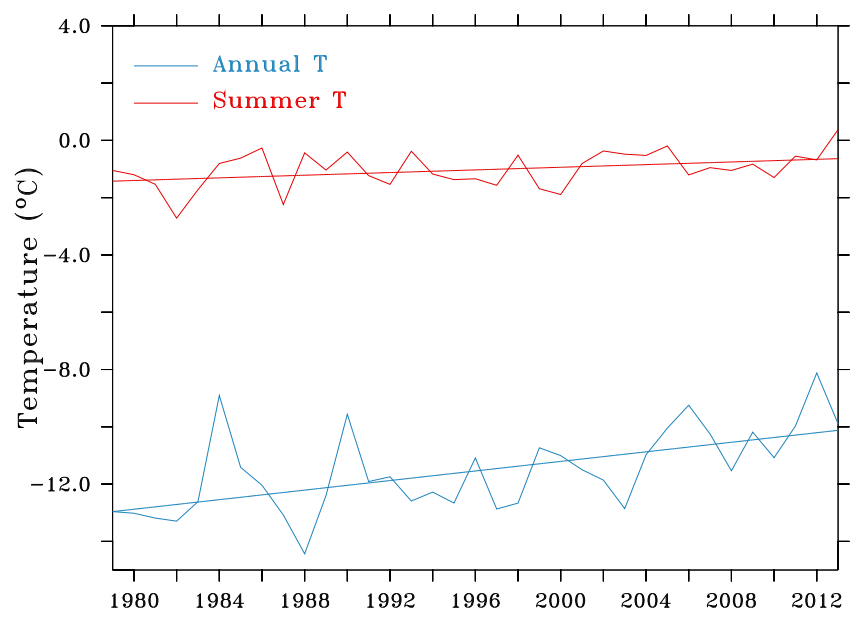

Figure 6. Evolution of the mean annual (blue) and summer (red) MAR $_{\text {ERA }}$ TAS $\left({ }^{\circ} \mathrm{C}\right)$ integrated over the permanent ice area between 1979 and 2013 with their linear trend.

HadRM3 RCM (as the ice cores of Pinglot et al. (1999) were retrieved in the accumulation zone). Their biases are similar for the Aust 98 stake, but we have better results at Vest 95 $\left(-0.11 \mathrm{mw}\right.$.e. $\mathrm{yr}^{-1}$ vs. -0.24$)$. However, Day et al. (2012) results do not show a huge bias on Kongsvegen like ours do.

Finally, we can compare the MAR $\mathrm{ERA}_{\mathrm{E}}$ mean elevation change rate $\left(\mathrm{d} h / \mathrm{d} t\right.$ in $\left.\mathrm{yr}^{-1}\right)$ over $2003-2008$ to Moholdt et al. (2010) (Supplement Fig. S2, to be compared to Fig. 1 of Moholdt et al. (2010)). In northwestern Spitsbergen, MAR $_{\text {ERA }}$ simulates a thickening of the interior whereas the entirety of northwestern Spitsbergen is thinning in Moholdt et al. (2010) and in south Spitsbergen, MAR ERA $_{\text {barely sim- }}$ ulates the thickening on the east coast. As a result, the regionaly averaged thinning of northwestern Spitsbergen is underestimated and the averaged thinning of south Spitsbergen is overestimated (Table 7). On Austfonna and in northeastern Spitsbergen, on the other hand, the pattern of the mean elevation change rate compares well with Moholdt et al.

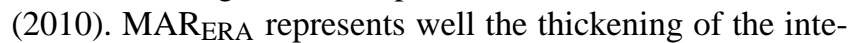
rior of Austfonna and northeastern Spitsbergen but slightly overestimates the margins thinning in northeastern Spitsbergen and slightly overestimates it on Austfonna. Regionally averaged, $\mathrm{d} h / \mathrm{d} t$ of northeastern Spitsbergen and Austfonna also compares well with Moholdt et al. (2010). Integrated over Svalbard, the MAR ERA mean elevation change is the same as Moholdt et al. (2010) $\left(-0.13 \mathrm{~m} \mathrm{yr}^{-1}\right.$ vs. $-0.12 \pm 0.04)$. MAR ${ }_{\text {ERA }}$ therefore compares well with Moholdt et al. (2010), considering the biases associated to the $10 \mathrm{~km}$ topography and the fact that only the first $\sim 10 \mathrm{~m}$ of ice and snow are modelled in MAR and that the compaction of the deep snow/ice layers is therefore not taken into account.

\section{Results of MAR over the present climate}

The mean annual total SMB integrated over Svalbard (Fig. 3a, black curve) simulated by MAR ERA $_{\text {between }}$ 1979 and 2013 is $-1.6 \pm 7.1 \mathrm{Gtyr}^{-1}$, corresponding to $-54 \pm 236 \mathrm{~mm}$ w.e. $\mathrm{yr}^{-1}$ with our ice sheet mask. The bias resulting from the use of a $10 \mathrm{~km}$ topography can be corrected based on the elevation classes histogram in Supplement Fig. S1 and gives an estimated mean annual value of $0.4 \mathrm{Gt} \mathrm{yr}^{-1}$ (corresponding to $12 \mathrm{~mm}$ w.e. $\mathrm{yr}^{-1}$ ), fully included in the uncertainty given here by the 1979-2013 interannual variability (standard deviation of $7.1 \mathrm{Gt}$ ). The high interannual variability is mainly a result of the variability of the meltwater runoff $\left(R^{2}=0.85\right.$ between the SMB and runoff), itself mainly due to the interannual variability of the JJA mean TAS. Based on measurements made in the 1960s-1990s, Hagen et al. (2003) estimated the SMB integrated over Svalbard to be $-14 \pm 3 \mathrm{mmw}$.e. $\mathrm{yr}^{-1}$ or $-0.5 \pm 0.1 \mathrm{Gtyr}^{-1}$. Our mean value of $-54 \mathrm{~mm}$ w.e. $\mathrm{yr}^{-1}$ over 1979-2013 therefore aligns with the values of Hagen et al. (2003), considering the large interannual variability of our SMB and the fact that the time period over which the simulations were performed are not the same (e.g. our mean value would have been $-36 \mathrm{~mm}$ w.e. $\mathrm{yr}^{-1}$ if we had not considered the year 2013). Calving has been estimated by Hagen et al. (2003) to be $4.5 \mathrm{Gt} \mathrm{yr}^{-1}\left(\sim 110 \mathrm{~mm}\right.$ w.e. $\left.\mathrm{yr}^{-1}\right)$ and is therefore a very important component of the net mass balance compared to their estimation of SMB. However, it is small compared to the contribution of surface runoff to the total mass loss (680 mm w.e. $\mathrm{yr}^{-1}$ in Hagen et al. (2003) and $695 \mathrm{~mm}$ w.e. $\mathrm{yr}^{-1}$ simulated by MAR $\mathrm{ERA}_{\mathrm{E}}$ ). Błaszczyk et al. (2009) estimated a calving flux of $6.75 \pm 1.75 \mathrm{~km}^{3} \mathrm{yr}^{-1}$ over 2000-2006 from ASTER imagery and we used this value to estimate SMB values from different mass balance (MB) estimates (Table 8). Considering again the large interannual variability of the SMB, our MAR ERA $_{\text {estimates compares }}$ well with Wouters et al. (2008) and the low value of Mémin et al. (2011) (corresponding to the MB of $-9.1 \mathrm{~km}^{3} \mathrm{yr}^{-1}$ ), both obtained from GRACE measurements. It also compares well with Nuth et al. (2010), knowing that the time period of their estimate is different from ours and different from the time period over which the calving flux was estimated. The high GRACE value of Mémin et al. (2011) (MB of $-15.5 \mathrm{~km}^{3} \mathrm{yr}^{-1}$ ) and the value obtained by ground gravity observations (MB of $-25 \mathrm{~km}^{3} \mathrm{yr}^{-1}$ ) give a surface loss much larger than ours but those values are also quite large compared to the other studies. To sum up, MAR ERA $_{\text {compares }}$ well with studies for which the SMB has been estimated and also gives satisfying results compared to other studies for which we had to estimate the SMB contribution using a calving flux value estimated over the same period.

SMB measurements starting in the 1960s on individual glaciers show a stability of the SMB until the late 1990s (Hagen et al. (2003) and references therein). The SMB of these glaciers located near the coast was negative, mean- 

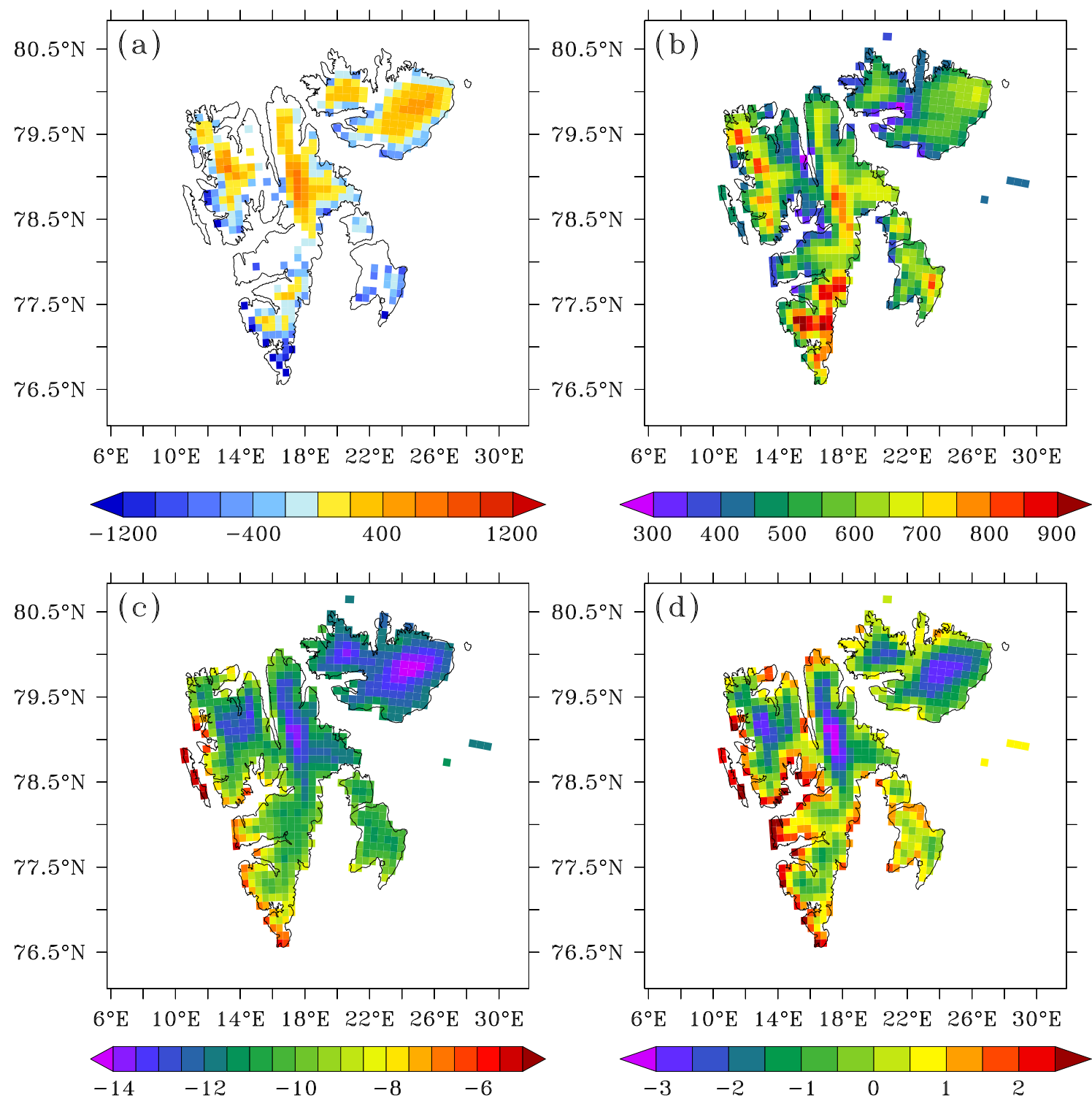

Figure 7. (a) Mean annual SMB (mmw.e. $\mathrm{yr}^{-1}$ ) averaged over 1979-2013. (b) Same as (a) for the annual precipitation (mmw.e. $\mathrm{yr}^{-1}$ ). (c) Same as (a) for the mean annual near-surface temperature (TAS) $\left({ }^{\circ} \mathrm{C}\right)$. (d) Same as (a) for the mean summer near-surface temperature $\left(\mathrm{TAS}_{\mathrm{JJA}}\right)\left({ }^{\circ} \mathrm{C}\right)$.

ing that the glaciers are losing mass but without any acceleration nor deceleration of the surface mass loss. However, some glaciers like Kongsvegen and Kronebreen experienced increased melting in the late 1990s (Nuth et al., 2012) but their SMB stabilised in the second half of the 2000s. Integrated over the entirety of Svalbard, the 1979-2013 linear temporal trend of the MARERA SMB $\left(-0.1 \mathrm{Gtyr}^{-2}\right)$ is not statistically significant and therefore suggests stability. Contrary to individual SMB measurements, we can not affirm that the integrated SMB is really negative as the averaged MAR $_{\text {ERA }}$ SMB is close to zero and given the biases associated to the used $10 \mathrm{~km}$ resolution. Moholdt et al. (2010) highlighted a very negative SMB in 2003-2004 followed by a series of more balanced values between 2004 and 2007 . MAR $_{\text {ERA }}$ also suggests very low values of SMB in 2003 and 2004 ( -12 Gt) and more balanced values over 2005-2012. We can therefore conclude that the SMB has been stable (yet negative) over the past 35 years when integrated over the entirety of Svalbard. The recent trend is however opposite to what has been occurring over the Greenland ice sheet, where the SMB has been stable until the end of the 1990s and record melts have been observed since 2006 and can be explained by the recent change in atmospheric flow frequencies in summer, causing more frequent southerly flows over Greenland but rather northerly flows over Svalbard in summer (Fettweis et al., 2013a). 


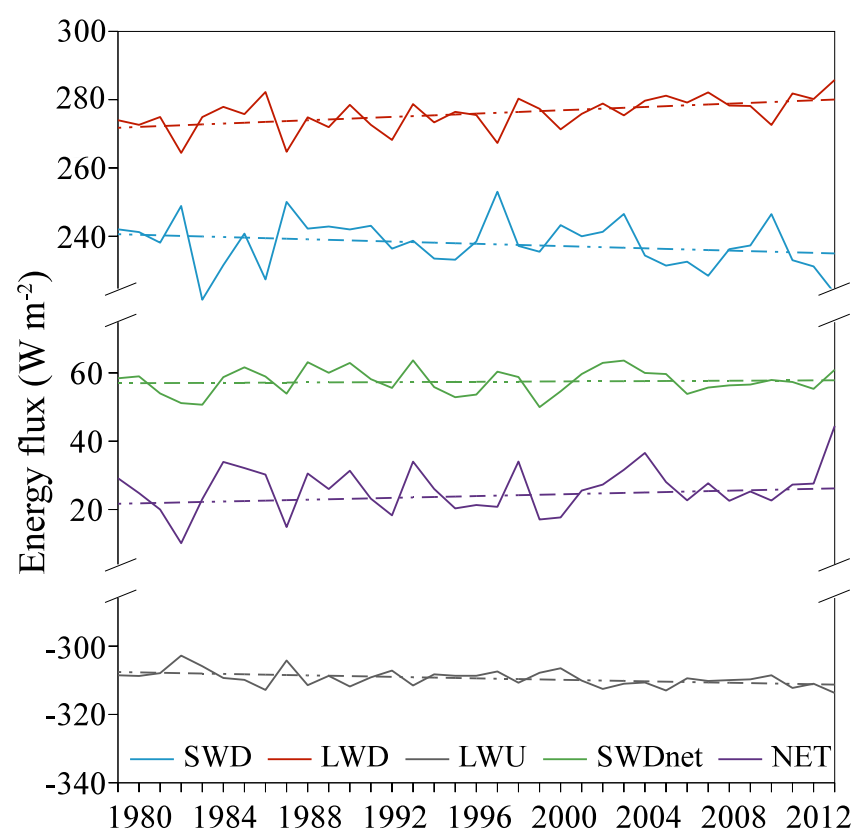

Figure 8. Evolution of the JJA energy balance components fluxes $\left(\mathrm{W} \mathrm{m}^{-2}\right)$ simulated by MAR $\mathrm{ERA}_{\mathrm{A}}$ over the permanent ice area with their linear trends in dashed lines.

Over Svalbard, the mean 1979-2005 summer $700 \mathrm{hPa}$ ERA-Interim atmospheric circulation was a westerly or west-southwesterly flow (Fig. 4a). After 2005, however, the circulation changed as a result of more frequent North Atlantic Oscillation (NAO) negative phases in summer. Z700 JJA (summer $700 \mathrm{hPa}$ geopotential height, representing the general circulation) increased more over Greenland than it did over Svalbard (Fig. 4b) resulting in northwesterly flows over Svalbard and more anticyclonic conditions over Greenland (Fettweis et al., 2013a). Consequently, a summer temperature increase breaking melt records has been observed over Greenland since 2006 (Fettweis et al., 2013a). Over Svalbard, on the contrary, the northerly flow brings colder air (Fig. 5b, showing temperature at $850 \mathrm{hPa}(\mathrm{T} 850)$ as it drives the melt variability, according to Fettweis et al. (2013b)), and the surface mass balance has remained stable over the period 1979-2012 despite the recent observed Arctic warming (Anisimov et al., 2007). In summer 2013, however, the $700 \mathrm{hPa}$ summer atmospheric circulation was again a westerly flow and could not oppose Arctic warming anymore. As a result, the 2013 JJA ERA-Interim T850 anomaly with respect to the 1979-2005 mean (Fig. 5c) was positive, contrary

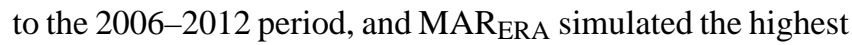
TAS $_{\text {JJA }}$ of the last 35 years (Fig. 6), causing the meltwater runoff to break records $\left(44.1 \mathrm{Gtyr}^{-1}\right)$. The $2013 \mathrm{MAR}_{\mathrm{ERA}}$ SMB was also the lowest of the last 35 years $\left(-20.4 \mathrm{Gt} \mathrm{yr}^{-1}\right)$, whereas the precipitation was higher than average but not significantly different (Fig. 3a).
The recent change in the $700 \mathrm{hPa}$ summer atmospheric circulation, damping the effect of the observed Arctic warming over Svalbard is also responsible for the stabilisation of the summer TAS (TAS $_{\text {JJA }}$ simulated by MAR ERA $_{\text {in Fig. 6) }}$ in the second half of the 2000s, as opposed to Greenland. Over the past 35 years, the annual Svalbard temperature has risen by $2.8^{\circ} \mathrm{C}$ as shown in Fig. 6 whereas the mean summer temperature increase is more moderate $\left(0.79^{\circ} \mathrm{C}\right.$ for the past 35 years). Both linear trends are statistically significant but, for the summer temperature, the very high value of 2013 has a large influence on the value of the trend given its position at the end of the time series. If we exclude summer 2013, the JJA temperature trend is not statistically significant.

While the mean annual values of precipitation and run-off are quite similar (18.7 and $20.9 \mathrm{Gt} \mathrm{yr}^{-1}$, Fig. 3a), the precipitation amount has been stable over 1979-2013 (interannual variability of $2.7 \mathrm{Gt} \mathrm{yr}^{-1}$ ), whereas the interannual variability of run-off is high $\left(7.4 \mathrm{Gtyr}^{-1}\right)$. Sublimation and evaporation, for their part, are quite constant and contribute very little to the SMB variability. Their negative values for every year indicate that MAR simulates a greater deposition than sublimation and evaporation. About $64 \pm 9 \%$ of the total liquid water (melt plus liquid precipitation) runs off and the remaining 36\% refreezes (Fig. 3b). Contrary to runoff and melt, the amount of water that refreezes is constant from year to year (standard deviation of $0.95 \mathrm{Gt} \mathrm{yr}^{-1}$ for the refreezing vs. $6.6 \mathrm{Gt} \mathrm{yr}^{-1}$ for the melt). Here again, none of the linear trends over 1979-2013 are significant.

The surface mass balance (Fig. 7a) is positive only on the ice caps on Nordaustlandet and in high elevation zones in north Spitsbergen where temperatures are low or precipitation high or both. The mean annual TAS (Fig. 7c) goes from $-5^{\circ} \mathrm{C}$ on the west coast of Spitsbergen to almost $-15^{\circ} \mathrm{C}$ in the centre of the ice caps and in Newtontoppen region (highest elevations, Fig. 2). Moreover, there is a west-toeast temperature gradient showing the effect of the North Atlantic Drift bringing oceanic heat to the west coast of the archipelago. This temperature gradient is enhanced by the larger SIC along the east coast that further cools it and increase the contrast with the west coast. The mean TAS JJA (Fig. 7d) is positive along the coasts, except in northeastern Spitsbergen and Austfonna where sea ice is still present in summer. The west-to-east gradient is less pronounced in summer than on the annual timescale as the sea ice strongly decreases on the east coast of Spitsbergen in summer. Precipitation (Fig. 7b) is lower on the west coast of Spitsbergen than on the east coast (e.g. on Austfonna) because of frequent depressions in the Barents Sea bringing humid air on the eastern coast of Svalbard (Winther et al., 1998; Hisdal, 1976). Due to the underestimation of the elevation, we can expect precipitation to be lower than observed as MAR likely underestimates the amount of humidity/clouds blocked by the mountains. The impact of the humidity underestimation on the longwave radiation also explains in part the MAR cold bias. According to Liestøl (1993), the maximum amount of 


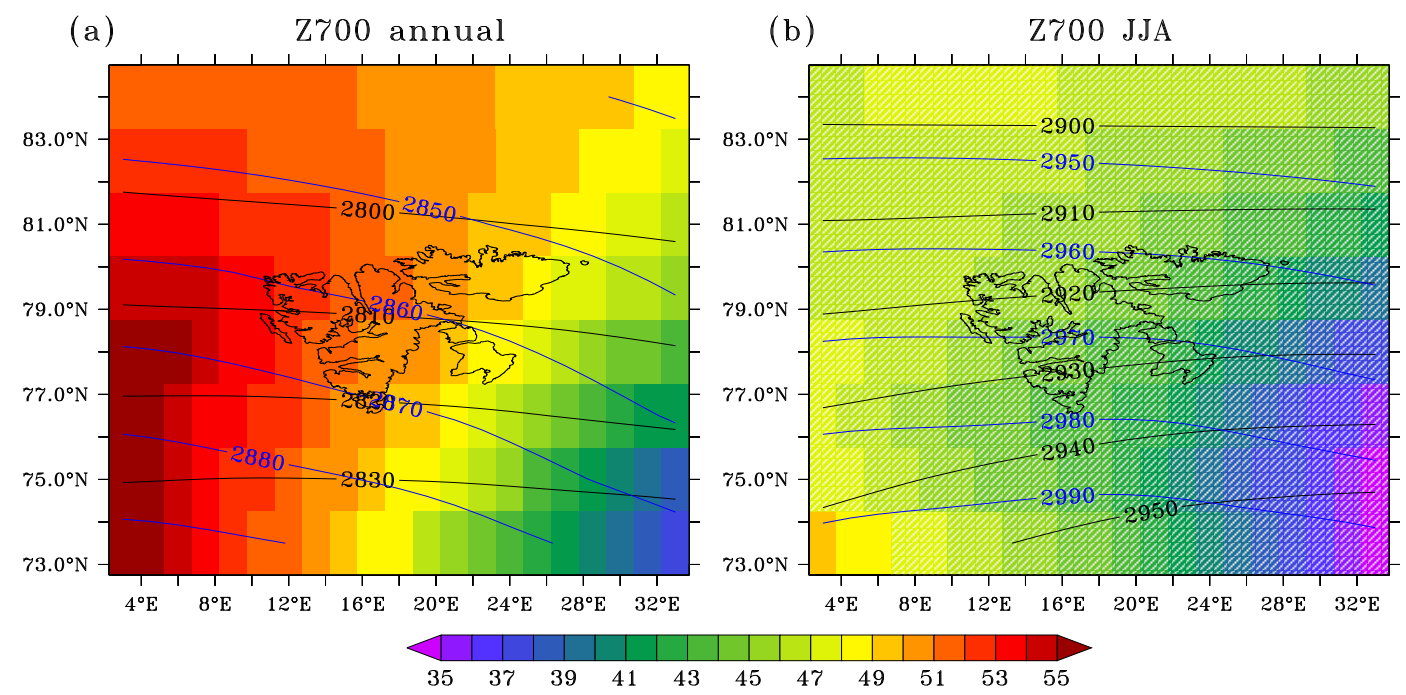

Figure 9. (a) Difference of mean annual geopotential height (m) at $700 \mathrm{hPa}$ (Z700) between MIROC5 and ERA-Interim over 1980-2005. The black lines show Z700 for ERA-Interim and the blue lines are for MIROC5. (b) Same as (a) but in summer (JJA). The non-hatched areas correspond to the areas for which the difference is significant at the $95 \%$ confidence level (with respect to the ERA-Interim-based 1980-2005 interannual variability), whereas the hatched areas corresponds to non-significant differences.
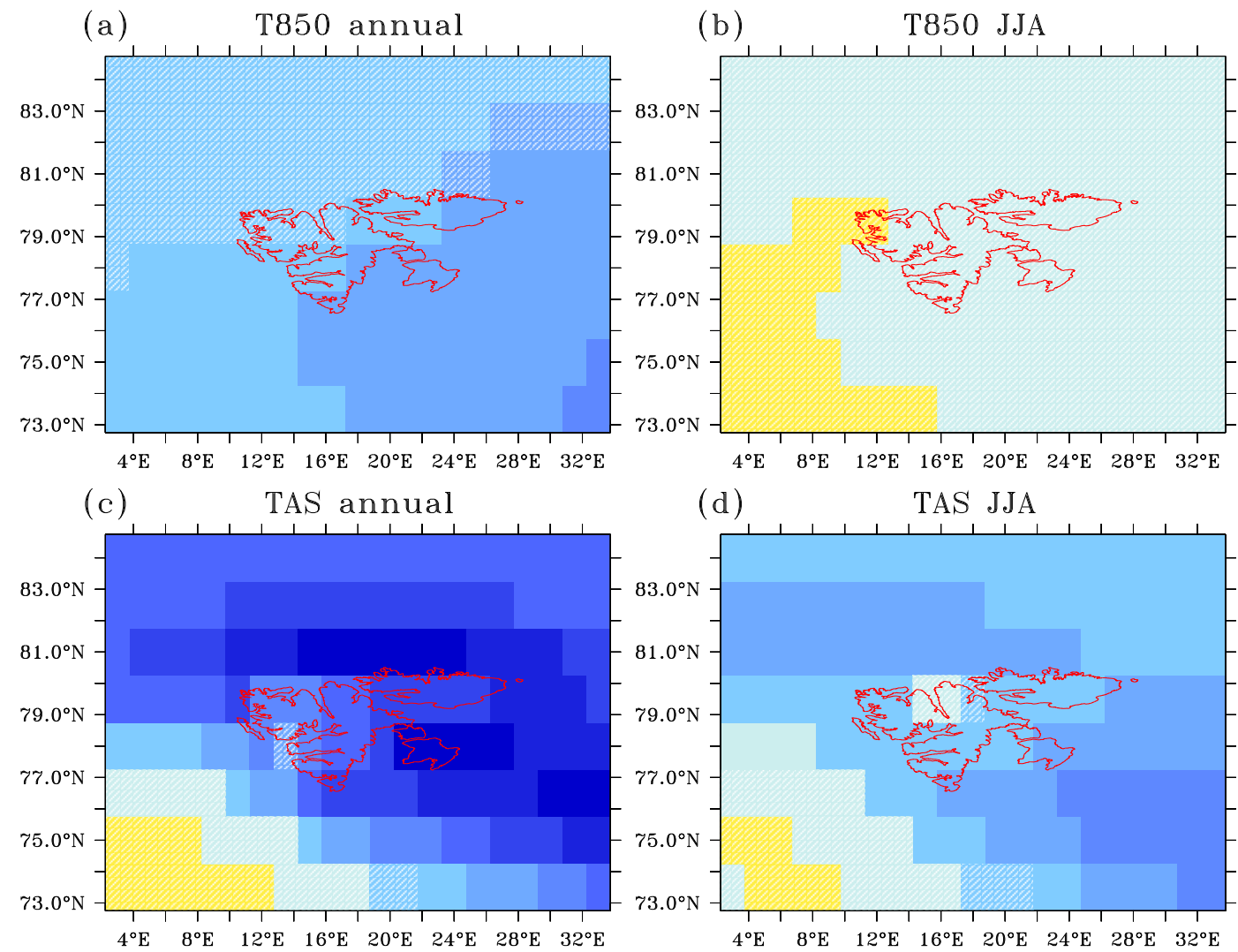

(d)

TAS JJA
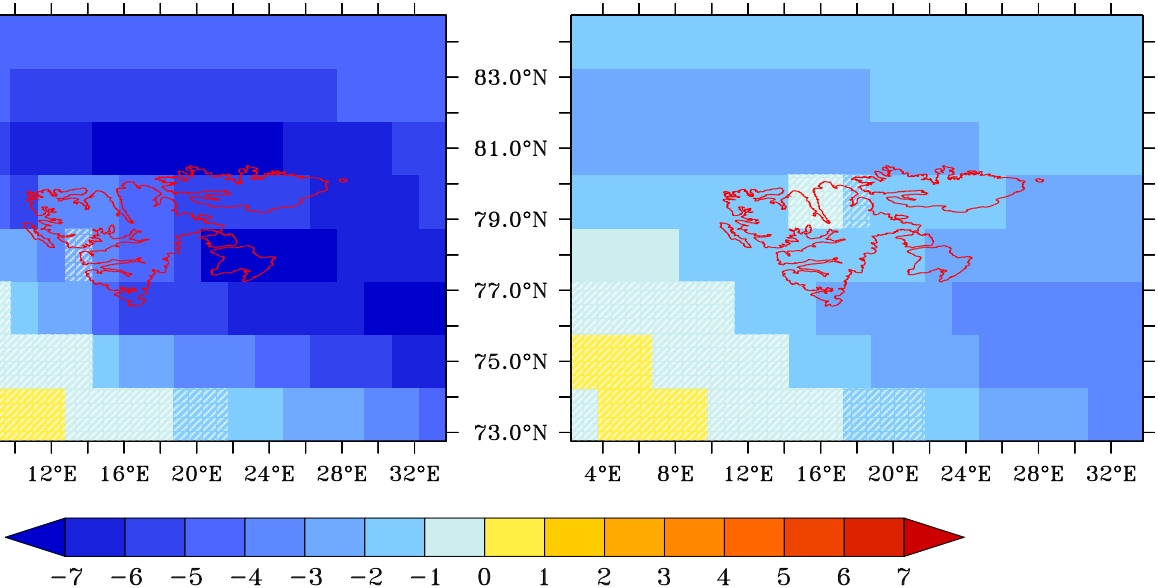

Figure 10. (a) Annual $850 \mathrm{hPa}$ temperature (T850) difference $\left({ }^{\circ} \mathrm{C}\right)$ between MIROC5 and ERA-Interim over 1980-2005. (b) Same as (a) but in summer (JJA). (c) Same as (a) but for the near-surface temperature (TAS, $\left.{ }^{\circ} \mathrm{C}\right)$. (d) Same as (c) but in summer (JJA). The non-hatched areas correspond to the areas for which the difference is significant at the $95 \%$ confidence level. 


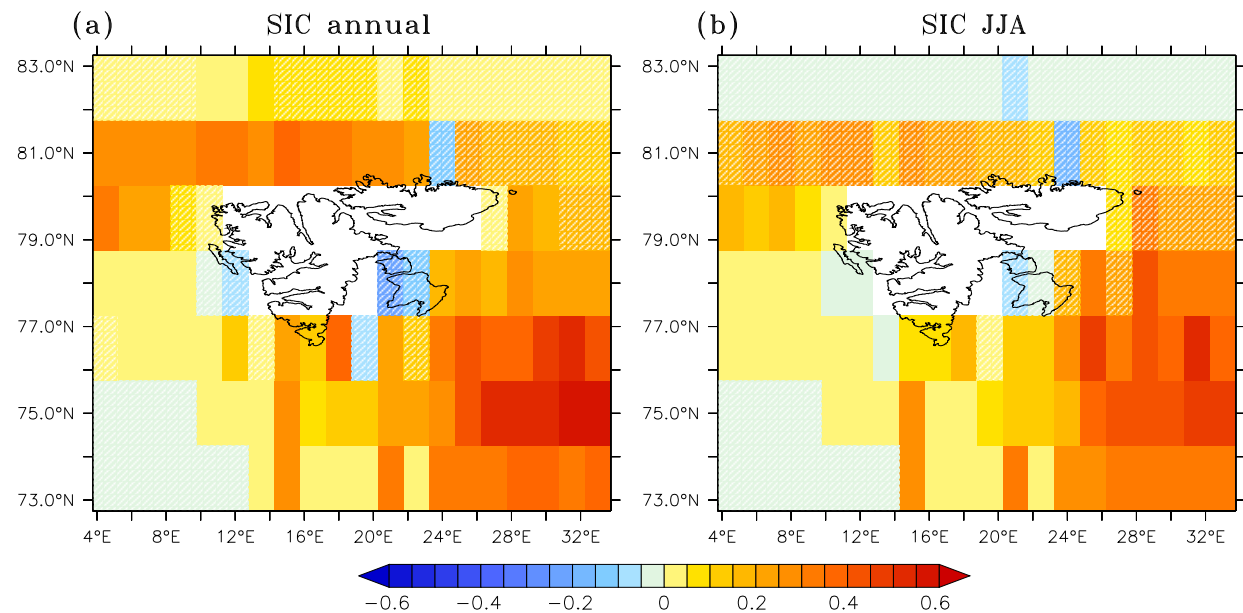

Figure 11. (a) Annual sea-ice cover (SIC) difference between MIROC5 and ERA over 1980-2005. The SIC go from zero to one according to the portion of the oceanic pixel covered in sea ice $(0=$ ice-free pixel, $1=$ pixel completely covered with sea ice). (b) Same as (a) but in summer (JJA). The non-hatched areas correspond to the areas for which the difference is significant at the $95 \%$ confidence level.
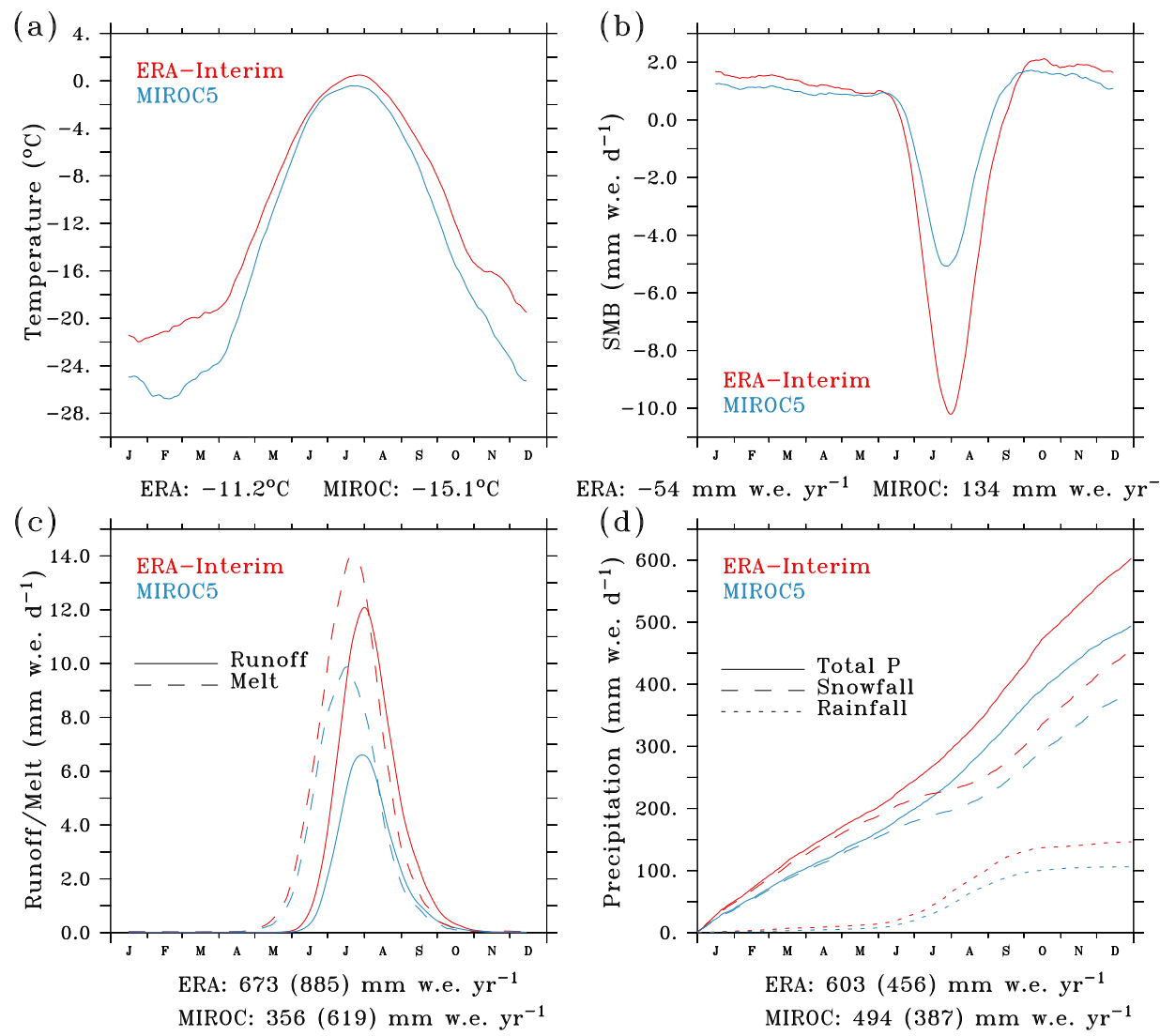

ERA: $-54 \mathrm{~mm}$ w.e. $\mathrm{yr}^{-1}$ MIROC: $134 \mathrm{~mm}$ w.e. $\mathrm{yr}^{-1}$

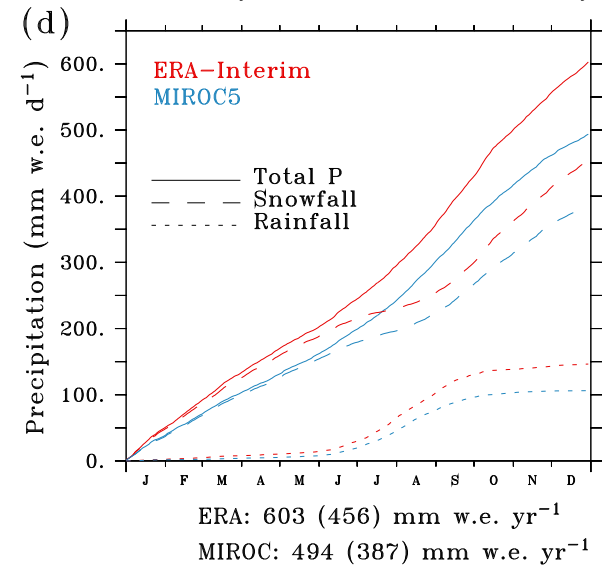

Figure 12. (a) 1980-2005 mean annual near-surface temperature cycle $\left({ }^{\circ} \mathrm{C}\right)$ for MAR $\mathrm{MRA}_{\text {(red) and MAR }}$ MIROC5 (blue). A $30-$ day running mean has been applied to smooth the curves. The numbers give the mean annual temperature integrated over the permanent ice area for MARERA and MAR MIROC5. (b) Same as (a) but for the surface mass balance (mmw.e. day ${ }^{-1}$ ). The numbers give the annual SMB

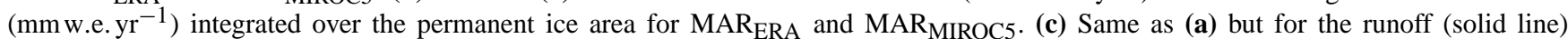
and melt (dashed line) (mmw.e. day $\left.{ }^{-1}\right)$. The listed numbers give the mean annual runoff, with the melt over the permanent ice area in brackets $\left(\mathrm{mm}\right.$ w.e. $\left.\mathrm{yr}^{-1}\right)$. (d) Same as (a) but for the cumulated total precipitation (solid line), snowfall (large dashes) and rainfall (small

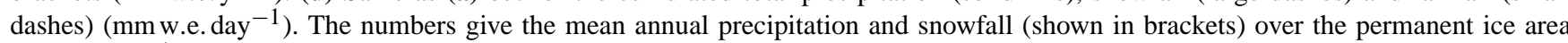
$\left(\mathrm{mm}\right.$ w.e. $\left.\mathrm{yr}^{-1}\right)$. 


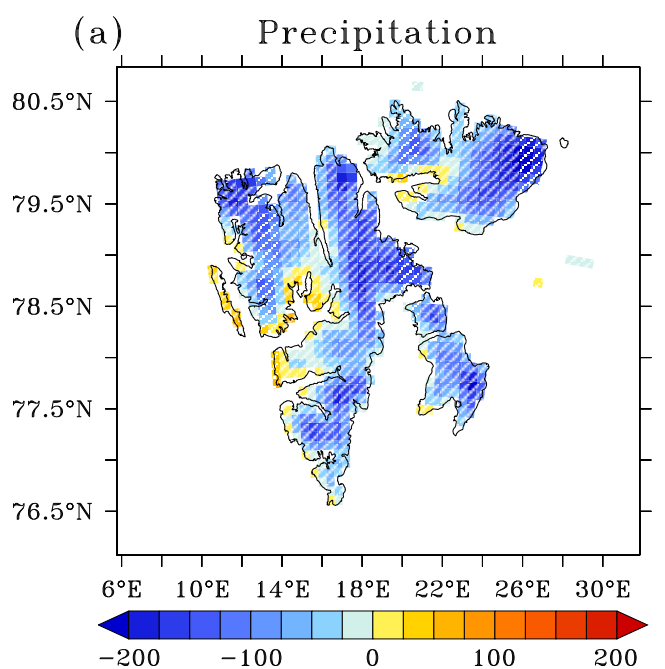

(b) Annual TAS
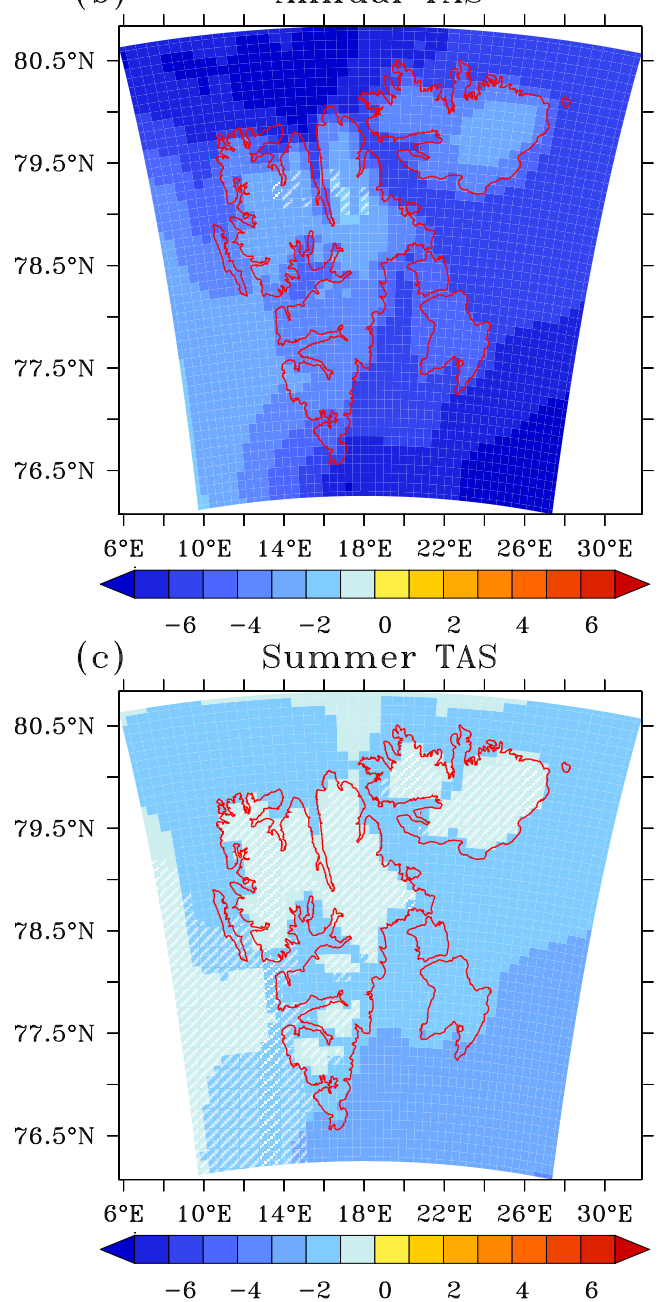

Figure 13. (a) Annual precipitation difference $\left(\mathrm{mm} \mathrm{yr}^{-1}\right)$ between

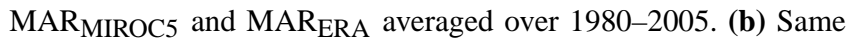
as (a) but for the annual near-surface temperature $\left({ }^{\circ} \mathrm{C}\right)$. (c) Same as (b) but for summer (JJA). The non-hatched areas correspond to the areas where the difference is significant (i.e. higher than twice the interannual variability of MAR $\mathrm{ERA}_{\text {). }}$

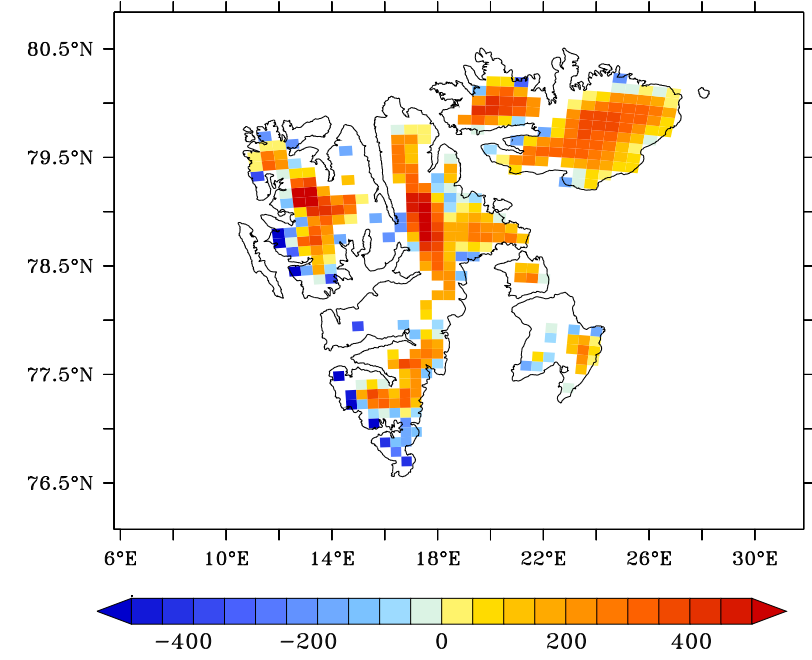

Figure 14. 1980-2005 mean annual SMB (mm w.e. $\mathrm{yr}^{-1}$ ) modelled by $\mathrm{MAR}_{\text {MIROC5}}$.

precipitation (more than $1000 \mathrm{~mm}$ ) is found in the southeastern part of Spitsbergen, where the wind transports humid air onto the mountain slopes. In our case, the maximum is also located in the south of Spitsbergen but it is underestimated (900-950 mm).

The net energy flux (NET) available at the surface for the melt can be written

$\mathrm{NET}=$ SWDnet + LWnet $+\mathrm{SHF}+\mathrm{LHF}\left(\mathrm{W} \mathrm{m}^{-2}\right)$,

where

- SWDnet $=$ SWD $\times(1-a)$ is the net downward shortwave radiation, i.e. the amount of the downward shortwave (= solar radiation) energy flux (SWD) that is absorbed by the surface following its albedo (a).

- LWnet $=$ LWD-LWU is the net longwave radiation, i.e. the difference between the downward longwave radiation coming from the atmosphere and the upward longwave radiation emitted by the surface.

- SHF and LHF are the sensible and latent heat fluxes. These fluxes are negligible with respect to the solar and infrared fluxes and are therefore not shown in Fig. 8.

Over 1979-2013, the net energy flux at the surface in summer has increased (Fig. 8), as a result of increases in both net downward shortwave (SWDnet) and longwave (LWDnet) summer energy fluxes, giving more energy for the melt. However, only the longwave energy fluxes linear trends are significant. As the summer SWD has been decreasing, the dominant factor causing the increase of SWDnet over 19792013 is the decrease of the surface albedo. The increase in LWD is a consequence of the increasing greenhouse effectinduced atmosphere warming as well as the significant increase of summer cloud cover $(5 \%$ in 35 years with a 1979 2013 mean cloud cover of $73 \pm 3 \%$ ). The cloudiness increase 
is also responsible for the SWD decrease through the greater reflection of the sunlight by the clouds.

\section{Comparison of ERA-Interim and MIROC5 over Svalbard}

With the aim of performing future projections with MAR in a companion paper (Lang et al., 2014), we need a global model (GCM) to force its lateral boundaries, and we need to be sure that MAR forced by the GCM is able to correctly simulate the current climate over Svalbard. Indeed, the future projections will be more uncertain if MAR forced by the GCM shows huge biases over the present. Given the dependency of RCM outputs to the forcings (Fettweis et al., 2013b), it is first necessary to evaluate the GCM itself over Svalbard to be able to explain the possible biases when MAR is forced by the GCM with respect to MAR forced by ERA-Interim (chosen here as reference over current climate as in Fettweis et al., 2013b). Suitable GCMs are those that are capable of modelling the free atmosphere as MAR is not able to correct possible biases in the free atmosphere in view of the dimension of our integration domain. To achieve this, we have compared Z700, representing the atmospheric circulation and T850, as well as TAS and SIC, as MAR is forced by SST and SIC over ocean. Among the CMIP5 models evaluated in Fettweis et al. (2013b), MIROC5 (Model for Interdisciplinary Research On Climate, Watanabe et al., 2010; Sakamoto et al., 2012) is one of the best GCMs over Greenland with respect to ERA-Interim. The MIROC5 global model works also well over Svalbard as we will show hereafter. As the historical run ends in 2005, the comparison period extends here from 1980 to 2005.

According to Fig. 9, the annual mean MIROC5-based Z700 is higher than ERA's by about 40 to $55 \mathrm{~m}$. The annual positive anomaly is significant at the $95 \%$ confidence level (for clarity, the significant anomalies correspond to the non-hatched areas) whereas the summer difference barely is. We consider the difference significant at the $95 \%$ confidence level if it is higher than twice the standard deviation of the ERA-Interim-based Z700 (representing the interannual variability of Z700). The solid lines, showing the mean Z700, suggests that the circulation is slightly diverted (clockwise for the annual circulation and anticlockwise for the JJA circulation), from ERA-Interim to MIROC5 going from a westerly flow in ERA to a west-northwesterly flow in MIROC5. At the annual timescale (1980-2005), MIROC5 is colder at $850 \mathrm{hPa}$ than ERA-Interim by 2 to $4^{\circ} \mathrm{C}$, and this difference is significant over the south and east of Svalbard (Fig. 10a, annual mean). In summer, this T850 anomaly is not significant (Fig. 10b). At the surface (TAS, Fig. 10c and d), the cold bias is even larger, especially at the annual timescale, except in the southwestern corner, where we have a non-significant positive bias. Contrary to the JJA T850 anomaly, the TAS ${ }_{\text {JJA }}$ cold bias of MIROC5 with respect to ERA-Interim is significant.

The temperature difference is linked in part to the larger SIC in MIROC5 with respect to ERA-Interim (Fig. 11). The only zone where the temperature anomaly is positive corresponds to the zone where the MIROC5 SIC is lower than the ERA-Interim SIC. Conversely, the area in the southeastern corner where MIROC5 prescribes more than $50 \%$ of ice coverage, whereas the ocean is mostly ice free with ERA, corresponds to the zone where MIROC5 is the coldest compared to ERA-Interim.

Contrary to air temperatures that are forced only at the lateral boundaries of our integration domain, SIC and sea surface temperatures (SST) are 6 hourly forced over the entire MAR domain as MAR is not coupled with an oceanic model. Their biases therefore impact on the climate modelled by MAR, especially near the coast, where most of the weather stations are located.

\section{Comparison of MAR forced by ERA-Interim and MIROC5}

According to Fig. 12a showing the annual cycle of TAS,

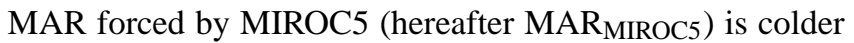
than MAR $_{\text {ERA }}$ through the whole year: during summer, the difference is close to zero, but it is larger than $5^{\circ} \mathrm{C}$ in winter. Integrated over the entirety of Svalbard, the annual SMB is positive with MAR MIROC5 $\left(+4.0 \mathrm{Gtyr}^{-1}\right.$ on average over 1980-2005, corresponding to $134 \mathrm{mmw}^{-e} \cdot \mathrm{yr}^{-1}$ ), whereas Svalbard loses mass on average with MAR ERA $\left(-1.6 \mathrm{Gt} \mathrm{yr}^{-1}\right.$ or $-54 \mathrm{~mm}$ w.e. $\left.\mathrm{yr}^{-1}\right)$ over $1980-2005$. The SMB differences occur mainly in summer through meltwater runoff (Fig. 12c) as the precipitation difference (Fig. 12d) between MAR ERA $_{\text {and MAR }}$ MIROC5 is much smaller than the runoff difference (only $58 \%$ of the MAR ERA $_{\text {runoff is mod- }}$ elled by MAR MIROC5 $_{\text {, whereas }} 82 \%$ of the total amount of MAR ERA snowfall is modelled). The melt season is shorter for MAR MIROC 5 than for MAR $_{\text {ERA }}\left(\sim 145\right.$ day yr $^{-1}$ vs. $\sim$

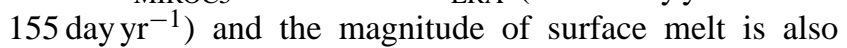
smaller $\left(68 \%\right.$ of the amount of melt in MAR $\left.\mathrm{ERA}_{\mathrm{A}}\right)$ with MAR $_{\text {MIROC5 (Fig. 12c). }}$

The amount of precipitation in MAR MIROC5 $_{\text {is lower than }}$

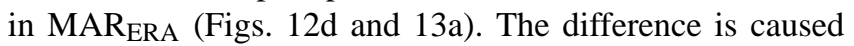
by (i) the cold bias of MIROC5 (the atmosphere can contain less moisture) and (ii) the difference in SIC between ERA-Interim and MIROC5. When the ocean is covered with ice, the exchange of moisture between the ocean and the atmosphere is strongly reduced and so is the amount of water available for precipitation (Noël et al., 2014). An overestimation of SIC also results in a decrease of inland TAS (Noël et al., 2014). The larger SIC in MIROC5 therefore also causes MAR MIROC5 to be colder than MAR ERA, especially in the northwestern and southeastern corners of our integration domain according to Figs. $13 \mathrm{~b}$ and 11. The bias, still 
Table 9. 1980-2005 mean SMB, its components $\left(\mathrm{Gt} \mathrm{yr}^{-1}\right)$ and annual and JJA TAS $\left({ }^{\circ} \mathrm{C}\right)$ with their linear trends $\left(\mathrm{Gt} \mathrm{yr}^{-2}\right.$ and $\left.^{\circ} \mathrm{C} \mathrm{yr}{ }^{-1}\right)$ from

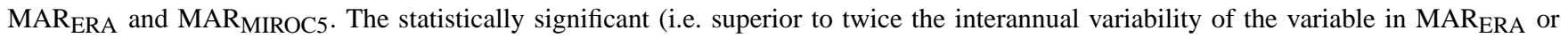

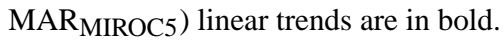

\begin{tabular}{lrrrrr}
\hline & \multicolumn{2}{c}{ Mean $\left(\mathrm{Gt} \mathrm{yr}^{-1}-{ }^{\circ} \mathrm{C}\right)$} & & \multicolumn{2}{c}{$\operatorname{Trend}\left(\mathrm{Gt} \mathrm{yr}^{-2}-{ }^{\circ} \mathrm{C} \mathrm{yr}^{-1}\right)$} \\
\cline { 2 - 3 } \cline { 5 - 6 } & $\mathrm{MAR}_{\text {ERA }}$ & $\mathrm{MAR}_{\text {MIROC5 }}$ & & MAR $_{\text {ERA }}$ & $\mathrm{MAR}_{\text {MIROC5 }}$ \\
\hline SMB & -1.6 & 4.0 & & -0.2 & $\mathbf{- 0 . 6}$ \\
Runoff & 20.2 & 10.7 & & 0.2 & $\mathbf{0 . 7}$ \\
Precipitation & 18.1 & 14.8 & & -0.004 & 0.1 \\
Sublimation/evaporation & -0.57 & 0.15 & & -0.007 & -0.02 \\
Temperature (annual) & -11.2 & -15.1 & & 0.05 & 0.1 \\
Temperature (summer) & -0.9 & -1.9 & & 0.03 & $\mathbf{0 . 0 7}$ \\
\hline
\end{tabular}

greater than $1.0^{\circ} \mathrm{C}$ in the high elevation central regions in the north of Spitsbergen and in the interior of Austfonna, indicates that Svalbard is extremely impacted by the sea surface conditions, even far inland. However, this TAS negative anomaly is also induced by the MIROC5-based free atmosphere, which is too cold at the MAR lateral boundaries. Due to positive feedbacks, it is likely that the SIC overestimation and the too-cold free atmosphere are linked in MIROC5.

Finally, the TAS bias is reduced over land (about $1.5^{\circ} \mathrm{C}$ for the annual bias and $1^{\circ} \mathrm{C}$ in summer, Fig. 13b and c) in MAR $_{\text {MIROC5 }}$ compared to the MIROC5 bias and becomes

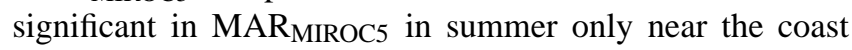
where the sea-ice bias has the greatest influence (Noël et al., 2014), suggesting that MAR is really able to improve the MIROC5 inputs (showing a significant cold bias over most of the land area).

Over 1980-2005, the SMB simulated by MAR ERA (Fig. 7 also holds for the 1980-2005 period, as the climate has been stable over the last 35 years) is positive only in the northwestern and northeastern central parts of Spitsbergen and on

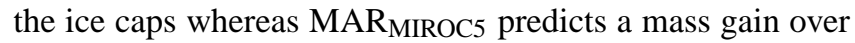
most of Svalbard (Fig. 14) due to the underestimation of the melt. The only locations where large amounts of mass are

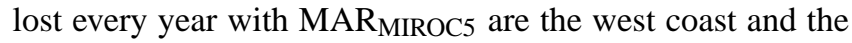
very southern part of Spitsbergen. Over the reference period,

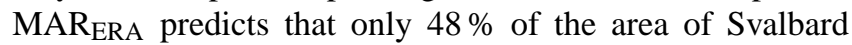
covered with permanent ice has a positive SMB while with MAR $_{\text {MIROC5 }}, 74 \%$ of this area gains mass on average. Integrated over the entirety of Svalbard, the SMB modelled by MAR $_{\text {MIROC5 }}$ is therefore positive (Table 9).

Over most of Svalbard, the MAR MIROC5 $_{\text {SMB is larger }}$ than the MAR ${ }_{E R A}$ SMB because of the run-off deficit in

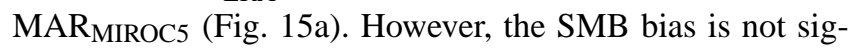
nificant, given its large interannual variability, except in some places in the very south of Spitsbergen and Edgeøya. The snowfall bias is almost never significant and the areas of significant runoff underestimation in MAR MIROC5 $_{\text {are }}$ mostly located where the JJA temperature bias is the largest (Fig. 15b and c). In the centre of northern Spitsbergen, the SMB modelled by MAR MIROC5 $_{\text {is lower than MAR }}$ ERA SMB (coincidently where the later is positive) as it corresponds to areas where the precipitation bias is the largest, likely as a result of too-low temperature in MIROC5 disallowing significant precipitation. In south Spitsbergen and on Edgeøya on the other hand, the precipitation modelled by MAR MIROC5 is less underestimated whereas the runoff bias is very negative, hence causing a largely positive SMB bias.

Whereas we saw in Sect. 4 that there has been no SMB temporal trend over the past 35 years according to MAR ${ }_{E R A}$, MAR $_{\text {MIROC5 }}$ shows a significant SMB trend $\left(-0.6 \mathrm{Gtyr}^{-2}\right.$, Fig. 3). The runoff and summer temperature trends are also significant, contrary to MAR $_{\text {ERA }}$ (Table 9). The negative SMB trend is due to the inability of MIROC5 to correctly represent the recent atmospheric circulation change damping the global warming impact over Svalbard, according to Fettweis et al. (2013a). As a result, the summer temperature rises significantly instead of remaining constant and the melt is overestimated in the second half of the 2000s.

\section{Conclusions}

In this study, MAR has been evaluated over Svalbard: although it is too cold, the modelled SMB is close to the measured one in areas where the $10 \mathrm{~km}$ resolution is enough to correctly represent the topography (i.e. on Austfonna). On Spitsbergen, on the other hand, the $10 \mathrm{~km}$ resolution is not able to resolve the complex topography and therefore the precipitation pattern. As a result, large biases in the SMB are present and higher resolutions are therefore needed to correctly simulate the SMB in this area.

What has been observed on several glaciers between the 1960s and the 1990s has been extended to the present day over the entirety of Svalbard in this study: there has been no significant temporal change of the surface mass balance over the last 35 years despite the global change-induced Arctic warming observed since the end of 1990s (Serreze et al., 2009). Because of the recent change in atmospheric circulation in summer (favouring northwesterly flow over Svalbard), there has not been any recent record surface melt in Svalbard 


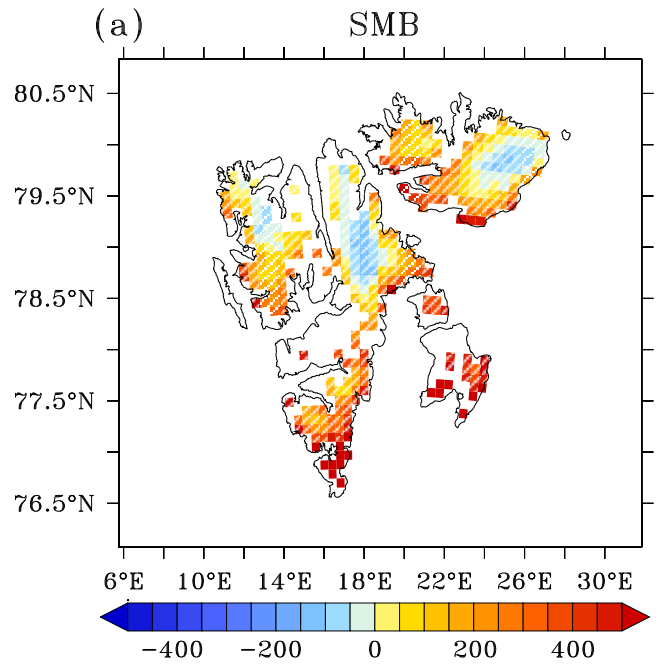

(b)
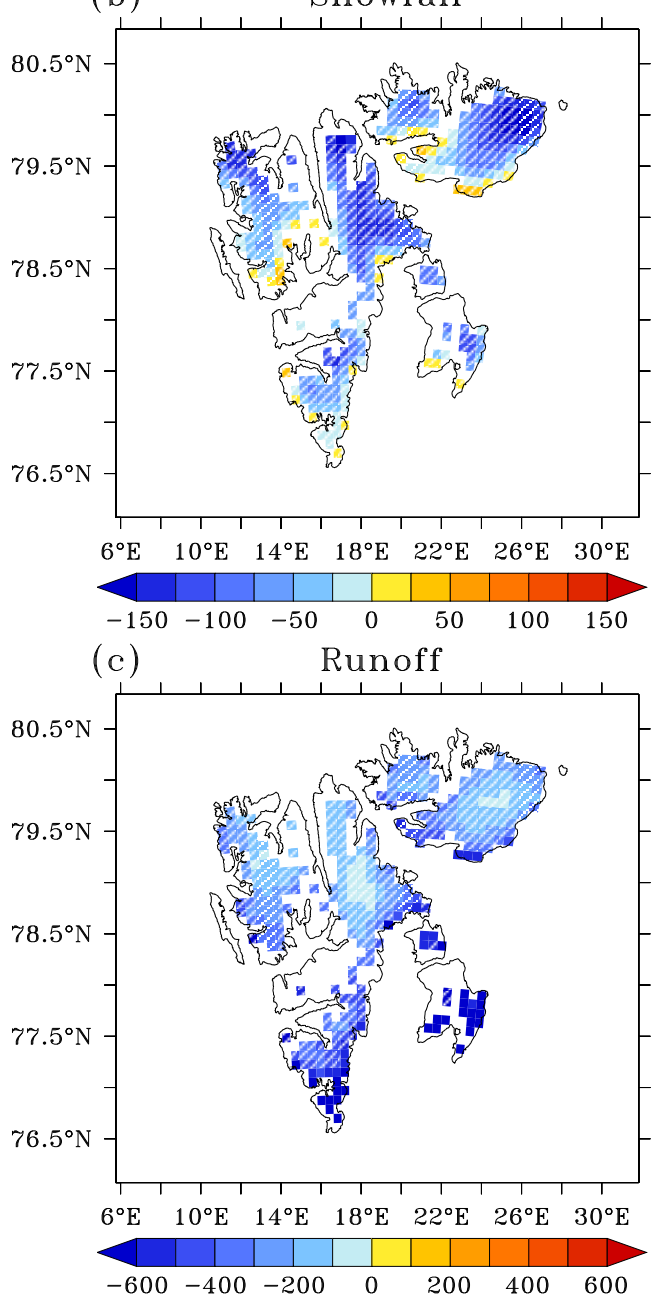

Figure 15. (a) Annual SMB difference (mmw.e. $\mathrm{yr}^{-1}$ ) between

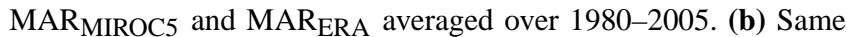
as (a) but for the snowfall (mmw.e. $\mathrm{yr}^{-1}$ ). (c) Same as (a) but for the runoff ( $\mathrm{mm}$ w.e. $\mathrm{yr}^{-1}$ ). The non-hatched areas correspond to the areas where the difference is significant. like in Greenland until 2013. In 2013 on the other hand, the atmospheric circulation was again a westerly flow over Svalbard, causing the SMB to break a record in Svalbard whereas the melt was much more moderate in Greenland. This shows the important role of general circulation anomalies in summer and the need to have time series long enough to know if these recent circulation changes are due to natural variability or not.

With the perspective of performing future simulations, we have compared MIROC5 and ERA-Interim over Svalbard as well as MAR forced by MIROC5 and ERA-Interim over 1980-2005. Averaged over 1980-2005, MIROC5 is significantly colder than ERA-Interim and prescribes more sea ice that impacts the temperature over land and the precipitation simulated by MAR. MAR MIROC5, however, has proven able to improve the MIROC5 results, and the SMB, runoff and precipitation differences to the MAR $\mathrm{ERA}_{\mathrm{E}}$ simulations are barely significant. In summer, the near-surface temperature difference over the land is significant only close to the coastline.

If we look at the temporal evolution of the SMB, on the other hand, MAR MIROC5 $_{\text {SMB shows a significant negative }}$

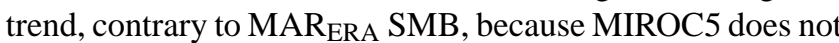
represent the recent atmospheric change that caused the SMB of Svalbard to remain constant on average. However, integrated over the entirety of Svalbard, the differences are not statistically significant, suggesting that the MIROC5-forced future projections should not be affected a lot by the biases over current climate with respect to the ERA-Interimforced run.

\section{The Supplement related to this article is available online at doi:10.5194/tc-9-83-2015-supplement.}

Acknowledgements. C. Lang works under a $\mathrm{PhD}$ grant from the Fonds pour la formation à la Recherche dans l'Industrie et l'Agriculture (FRIA), Belgium. The meteorological data come from the Norwegian Meteorological Institute (www.eklima.no). The authors wish to thank J. Kohler and the Norsk Polarinstitutt for providing us the topography and C. Nuth for the ice mask. We also thank one anonymous reviewer, J. Lenaerts, M. Pelto and C. Rye, whose comments helped improve this manuscript a lot.

Edited by: J. O. Hagen 


\section{References}

Anisimov, O. A., Vaughan, D. G., Callaghan, T. V., Furgal, C., Marchant, H., Prowse, T. D., Vilhjálmsson, H., Walsh, J. E., Parry, M. L., Canziani, O. F., Palutikof, J. P., van der Linden, P. J., and Hanson, C. E. (Eds.): Polar Regions (Arctic and Antarctic), Climate Change 2007: Impacts, Adaptation and Vulnerability. Contribution of Working Group II to the Fourth Assessment Report of the Intergovernmental Panel on Climate Change, Cambridge University Press, Cambridge, 653-685, 2007.

Bamber, J. L., Krabill, W., Raper, V., and Dowdeswell, J. A.: Anomalous recent growth of part of a large Arctic ice cap: Austfonna, Svalbard, Geophys. Res. Lett., 31, L12402, doi:10.1029/2004GL019667, 2004.

Bamber, J. L., Krabill, W., Raper, V., Dowdeswell, J. A., and Oerlemans, J.: Elevation changes measured on Svalbard glaciers and ice caps from airborne laser data, Ann. Glaciol., 42, 202-208, 2005.

Benestad, R. E., Førland, E. J., and Hanssen-Bauer, I.: Empirically downscaled temperature scenarios for Svalbard, Atmos. Sci. Lett., 3, 71-93, doi:10.1006/asle.2002.0051, 2002.

Błaszczyk, M., Jania, J. A., and Hagen J. O.: Tidewater glaciers of Svalbard: Recent changes and estimates of calving fluxes, Pol. Polar Res., 30, 85-142, 2009.

Brun, E.: Investigation on wet-snow metamorphism in respect of liquid-water content, Ann. Glaciol., 13, 22-26, 1989.

Claremar, B., Obleitner, F., Reijmer, C., Pohjola, V., Waxegård, A., Karner, F., and Rutgersson, A.: Applying a Mesoscale Atmospheric Model to Svalbard Glaciers, Adv. Meteorol., 2012, 321649, doi:10.1155/2012/321649, 2012.

Day, J. J., Bamber, J. L., Valdes, P. J., and Kohler, J.: The impact of a seasonally ice free Arctic Ocean on the temperature, precipitation and surface mass balance of Svalbard, The Cryosphere, 6 , 35-50, doi:10.5194/tc-6-35-2012, 2012.

Dee, D. P., Uppala, S. M., Simmons, A. J., Berrisford, P., Poli, P., Kobayashi, S., Andrae, U., Balmaseda, M. A., Balsamo, G., Bauer, P., Bechtold, P., Beljaars, A. C. M., van de Berg, L., Bidlot, J., Bormann, N., Delsol, C., Dragani, R., Fuentes, M., Geer, A. J., Haimberger, L., Healy, S. B., Hersbach, H., Hólm, E. V., Isaksen, L., Kållberg, P., Köhler, M., Matricardi, M., McNally, A. P., Monge-Sanz, B. M., Morcrette, J.-J., Park, B.-K., Peubey, C., de Rosnay, P., Tavolato, C., Thépaut, J.-N., and Vitart, F.: The ERA-interim reanalysis: configuration and performance of the data assimilation system, Q. J. Roy. Meteor. Soc., 137, 553-597, doi:10.1002/qj.828, 2011.

de Ridder, K. and Gallée, H.: Land surface-induced regional climate change in Southern Israel, J. Appl. Meteorol., 37, 14701485, 1998.

de Woul, M. and Hock, R.: Static mass-balance sensitivity of Arctic glaciers and ice caps using a degree-day approach, Ann. Glaciol., 42, 217-224, 2005.

Fettweis, X., Hanna, E., Lang, C., Belleflamme, A., Erpicum, M., and Gallée, H.: Brief communication "Important role of the midtropospheric atmospheric circulation in the recent surface melt increase over the Greenland ice sheet", The Cryosphere, 7, 241248, doi:10.5194/tc-7-241-2013, 2013a.

Fettweis, X., Franco, B., Tedesco, M., van Angelen, J. H., Lenaerts, J. T. M., van den Broeke, M. R., and Gallée, H.: Estimating the Greenland ice sheet surface mass balance contribution to future sea level rise using the regional atmospheric cli- mate model MAR, The Cryosphere, 7, 469-489, doi:10.5194/tc7-469-2013, 2013b.

Førland, E. J., Benestad, R. E., Flatøy, F., Hanssen-Bauer, I., Haugen, J. E., Isaksen, K., Sorteberg, A., and Ådlandsvik, B.: Climate development in North Norway and the Svalbard region during 1900-2100, Norwegian Polar Institute Report 128, Troms $\varnothing$, Norway, 2009.

Førland, E. J., Benestad, R., Hanssen-Bauer, I., Haugen, J. E., and Skaugen, T. E.: Temperature and precipitation development at Svalbard 1900-2100, Adv. Meteorol., 2011, 893790, doi:10.1155/2011/893790, 2011.

Franco, B., Fettweis, X., and Erpicum, M.: Future projections of the Greenland ice sheet energy balance driving the surface melt, The Cryosphere, 7, 1-18, doi:10.5194/tc-7-1-2013, 2013.

Gallée, H. and Schayes, G.: Development of a three-dimensional meso- $\gamma$ primitive equation model: katabatic winds simulation in the area of Terra Nova Bay, Antarctica, Mon. Weather Rev., 122, 671-685, 1994.

Gallée, H., Guyomarc'h, G., and Brun, E.: Impact of snow drift on the Antarctic ice sheet surface mass balance: possible sensitivity to snow-surface properties, Bound.-Lay. Meteorol., 99, 1-19, 2001.

Gardner, A. S., Moholdt, G., Cogley, J. G., Wouters, B., Arendt, A. A., Wahr, J., Berthier, E., Hock, R., Pfeffer, W. T., Kaser, G., Ligtenberg, S. R.M, Bolch, T., Sharp, M. J., Hagen, J. O., van den Broeke, M. R., and Paul, F.: A reconciled estimate of glacier contributions to sea level rise: 2003 to 2009 , Science, 340, 852-857, 2013.

Hagen, J. O., Melvold, K., Pinglot, F., and Dowdeswell, J. A.: On the net mass balance of the glaciers and ice caps in Svalbard, Norwegian Arctic, Arct. Antarct. Alp. Res., 35, 264-270, 2003.

Hisdal, V.: Geography of Svalbard, 1 Edn., Norwegian Polar Research Institute, Oslo, Norway, 1976.

IPCC, Stocker, T. F., Qin, D., Plattner, G.-K., Tignor, M., Allen, S. K., Boschung, J., Nauels, A., Xia, Y., Bex, V., and Midgley, P. M. (Eds.): Climate Change 2013: The Physical Science Basis. Contribution of Working Group I to the Fifth Assessment Report of the Intergovernmental Panel on Climate Change, Cambridge University Press, Cambridge, UK and New York, NY, USA, 1535 pp., 2013.

Kaser, G., Cogley, J. G., Dyurgerov, M. B., Meier, M. F., and Ohmura, A.: Mass balance of glaciers and ice caps: consensus estimates for 1961-2004, Geophys. Res. Lett., 33, L19501, doi:10.1029/2006GL027511, 2006.

Lang, C., Fettweis, X., and Erpicum, M.: Future projections of the Svalbard climate and surface mass balance with the regional climate model MAR, The Cryosphere Discuss., 9, 115-140, doi:10.5194/tcd-9-115-2015, 2015.

Lefauconnier, B. and Hagen, J. O.: Glaciers and climate in Svalbard: Statistical analysis and reconstruction of the Brøggerbreen mass balance for the last 77 years, Ann. Glaciol., 14, 148-152, 1990.

Lenaerts, J. T. M., van Angelen, J. H., van den Broeke, M. R., Gardner, A. S., Wouters, B., and van Meijgaard, E.: Irreversible mass loss of Canadian Arctic Archipelago glaciers, Geophys. Res. Lett., 40, 870-874, doi:10.1002/grl.50214, 2013.

Liestøl, O.: Glaciers of Svalbard, Norway, US Geological Surv. Prof. Pap., 1386, E127-E151, 1993.

Mémin, A., Rogister, Y., Hinderer, J., Omang, O. C., and Luck, B.: Secular gravity variation at Svalbard (Norway) from ground 
observations and GRACE satellite data, Geophys. J. Int., 184, 1119-1130, doi:10.1111/j.1365-246X.2010.04922.x, 2011.

Moholdt, G., Nuth, C., Hagen, J. O., and Kohler, J.: Recent elevation changes of Svalbard glaciers derived from ICESat laser altimetry, Remote Sens. Environ., 114, 2756-2767, 2010.

Noël, B., Fettweis, X., van de Berg, W. J., van den Broeke, M. R., and Erpicum, M.: Sensitivity of Greenland Ice Sheet surface mass balance to perturbations in sea surface temperature and sea ice cover: a study with the regional climate model MAR, The Cryosphere, 8, 1871-1883, doi:10.5194/tc-8-1871-2014, 2014.

Nuth, C., Moholdt, G., Kohler, J., Hagen, J. O., and Kääb, A.: Svalbard glacier elevation changes and contribution to sea level rise, J. Geophys. Res., 115, F01008, doi:10.1029/2008JF001223, 2010.

Nuth, C., Schuler, T. V., Kohler, J., Altena, B., and Hagen, J. O.: Estimating the long-term calving flux of Kronebreen, Svalbard, from geodetic elevation changes and mass-balance modelling, J. Glaciol., 58, 119-133, doi:10.3189/2012JoG11J036, 2012.

Nuth, C., Kohler, J., König, M., von Deschwanden, A., Hagen, J. O., Kääb, A., Moholdt, G., and Pettersson, R.: Decadal changes from a multi-temporal glacier inventory of Svalbard, The Cryosphere, 7, 1603-1621, doi:10.5194/tc-7-1603-2013, 2013.

Pinglot, J. F., Pourchet, M., Lefauconnier, B., Hagen, J. O., Isaksson, E., Vaikmäe, R., and Kamiyama, K.: Accumulation in Svalbard glaciers deduced from ice cores with nuclear tests and Chernobyl reference layers, Polar Res., 18, 315-321, 1999.

Pinglot, J. F., Hagen, J. O., Melvold, K., and Eiken, T., and Vincent, C.: A mean net accumulation pattern derived from radioactive layers and radar soundings on Austfonna, Nordaustlandet, Svalbard, J. Glaciol., 47, 555-566, 2001.

Rasmussen, L. A. and Kohler, J.: Mass balance of three Svalbard glaciers reconstructed back to 1948, Polar Res., 26, 168-174, doi:10.1111/j.1751-8369.2007.00023.x, 2007.

Rye, C. J., Arnold, N. S., Willis, I. C., and Kohler, J.: Modeling the surface mass balance of a high Arctic glacier using the ERA-40 reanalysis, J. Geophys. Res.-Earth, 115, F02014, doi:10.1029/2009JF001364, 2010.

Rye, C. J., Willis, I. C., Arnold, N. S., and Kohler, J.: On the need for automated multiobjective optimization and uncertainty estimation of glacier mass balance models, J. Geophys. Res.-Earth, 117, F02005, doi:10.1029/2011JF002184, 2012.

Sakamoto, T. T., Komuro, Y., Nishimura, T., Ishii, M., Tatebe, H., Shiogama, H., Hasegawa, A., Toyoda, T., Mori, M., Suzuki, T., Imada, Y., Nozawa, T., Takata, K., Mochizuki, T., Ogochi, K., Emori, S., Hasumi, H., and Kimoto, M.: MIROC4h A new high-resolution atmosphere-ocean coupled general circulation model, J. Meteorol. Soc. Jpn., 90, 325-359, doi:10.2151/jmsj.2012-301, 2012.
Schuler, T. V., Loe, E., Taurisiano, A., Eiken, T., Hagen, J. O., and Kohler, J.: Calibrating a surface mass-balance model for Austfonna ice cap, Svalbard, Ann. Glaciol., 46, 241-248, 2007.

Serreze, M. C., Barrett, A. P., Stroeve, J. C., Kindig, D. N., and Holland, M. M.: The emergence of surface-based Arctic amplification, The Cryosphere, 3, 11-19, doi:10.5194/tc-3-11-2009, 2009.

Shepherd, A., Ivins, E. R., A, G., Barletta, V. R., Bentley, M. J., Bettadpur, S., Briggs, K. H., Bromwich, D. H., Forsberg, R., Galin, N., Horwath, M., Jacobs, S., Joughin, I., King, M. A., Lenaerts, J. T. M., Li, J., Ligtenberg, S. R. M., Luckman, A., Luthcke, S. B., McMillan, M., Meister, R., Milne, G., Mouginot, J., Muir, A., Nicolas, J. P., Paden, J., Payne, A. J., Pritchard, H., Rignot, E., Rott, H., Sørensen, L. S., Scambos, T. A., Scheuchl, B., Schrama, E. J. O., Smith, B., Sundal, A. V., van Angelen, J. H., van de Berg, W. J., van den Broeke, M. R., Vaughan, D. G., Velicogna, I., Wahr, J., Whitehouse, P. L., Wingham, D. J.,Yi, D., Young, D., and Zwally, H. J.: A reconciled estimate of of ice-sheet mass balance, Science, 338, 1183-1189, 2012.

van Pelt, W. J. J., Oerlemans, J., Reijmer, C. H., Pohjola, V. A., Pettersson, R., and van Angelen, J. H.: Simulating melt, runoff and refreezing on Nordenskiöldbreen, Svalbard, using a coupled snow and energy balance model, The Cryosphere, 6, 641-659, doi:10.5194/tc-6-641-2012, 2012.

Watanabe, M., Suzuki, T., O’ishi, R., Komuro, Y., Watanabe, S., Emori, S., Takemura, T., Chikira, M., Ogura, T., Sekiguchi, M., Takata, K., Yamazaki, D., Yokohata, T., Nozawa, T., Hasumi, H., Tatebe, H., and Kimoto, M.: Improved climate simulation by MIROC5: mean states, variability, and climate sensitivity, J. Climate, 23, 6312-6335, 2010.

Wilson, A. B., Bromwich, D. H., and Hines, K. M.: Evaluation of Polar WRF forecasts on the Arctic System Reanalysis domain: Surface and upper air analysis, J. Geophys. Res., 116, D11112, doi:10.1029/2010JD015013, 2011.

Winther, J.-G., Bruland, O., Sand, K., Killingtveit, ^., and Marechal, D.: Snow accumulation distribution on Spitsbergen, Svalbard, in 1997, Polar Res., 17, 155-164, 1998.

Wouters, B., Chambers, D., and Schrama, E. J. O.: GRACE observes small-scale mass loss in Greenland, Geophys. Res. Lett., 35, L20501, doi:10.1029/2008GL034816, 2008. 